\title{
The Abolition Of Culpability After Converting To Islam In The Science Of Hadîth And Hadîth Al-Ahkâm Perspective
}

\author{
Nuryamin ${ }^{1}$, Mohamad Anton Athoillah ${ }^{2}$
}

\begin{abstract}
The Abolition Of Culpability After Converting To Islam In The Science Of Hadîth And Hadîth Al-Ahkâm Perspective. This article examines the authenticity of the hadith concerning the abolition of one's culpability after converting to Islam as contained in Shahîh al-Bukhârî, Kitab al-Îmân, Bâb Husn Islâm al-Mar'. The method used in this research is the takhrîj al-badith method, which is a method to find the strength of the authenticity of hadîth by tracing it to its source. This research found the fact that in the narrative, many hadîth in the book Shahîh $\underline{h}$ al-Bukhârî are often classified as Hadith al-mu'allaq (Suspended Hadith) without considering the statements or explanations of the commentators. The status of a hadith which is categorized as $d h a^{\prime} \hat{\imath} f$ (weak) because the sanad (chain of narrators) is munqathi ' (broken), but after tracking other sanad there is an indication that the hadith is connected to the Prophet so that the status is shahîh (authentic). This has been the agreement of the scholars, except for Ibn $\underline{H}$ azm. In conclusion, not all hadîths, categorized as Mu'alla, can be categorized as $d h a^{\prime} \hat{\imath} f$ (weak) because the sanad is munqathi ((the narrator's chain is broken); As, in many cases, there are many such hadîths, after tracking through other means, it turns out to be connected to the Prophet; One of which is the hadith regarding the elimination of past mistakes of an infidel who later converted to Islam.
\end{abstract}

Keywords: conversion to Islam, hadith al-mu'allaq, hadîth al-abkâm, fiqh

Abstrak: Penghapusan Dosa Sesudah Konversi ke Agama Islam dari Perspektif Ilmu

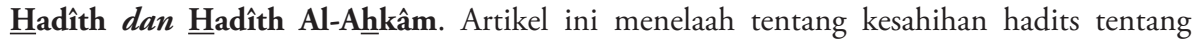
penghapusan culpability seseorang setelah masuk Islam sebagaimana terdapat dalam Shahîh al-Bukhârî, Kitab al-Îmân, Bâb Husn Islâm al-Mar'. Metode yang digunakan dalam penelitian

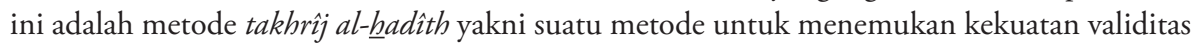
suatu $\underline{h} a d \hat{t} t h$ dengan cara melacak $\underline{h} a d \hat{t} t h$ itu ke sumber asalnya. Penelitian ini menemukan fakta bahwa dalam periwayatannya, banyak hadîth dalam kitab Shahîh $\underline{h}$ al-Bukhârî sering diklasifikasikan sebagai Hadits al-mu'allaq (Hadith yang tergantung) tanpa mempertimbangkan pernyataan atau penjelasan dari para komentatornya. Padahal, status riwayat hadith yang dikategorikan dha'îf (lemah) karena sanad-nya munqathi' (rantai naratornya terputus) namun setelah dilakukan pelacakan sanad yang lain ditemukan petunjuk bahwa hadits tersebut bersambung kepada Nabi, sehingga statusnya adalah shahbîh (valid). Hal ini telah menjadi kesepakatan para Ulama, kecuali Ibn Hazm. Kesimpulannya, tidak semua hadìth yang dikategorikan Mu'allaq dapat dikategorikan dha'îf(lemah) karena sanad-nya munqathi'.

${ }^{1}$ Sekolah Tinggi Agama Islam Baitul Arqam Al-Islamy Bandung

${ }^{2}$ Universitas Islam Negeri Sunan Gunung Djati Bandung

E-mail: 'knoer09@gmail.com, 2anton_athoillah@uinsgd.ac.id 


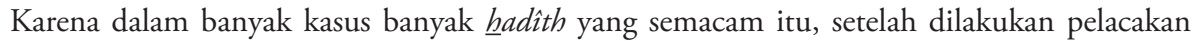
melalui sanad yang lain, ternyata bersambung kepada Nabi, salah satunya hadits tentang penghapusan kesalahan di masa lalu seorang yang kafir yang kemudian masuk Islam.

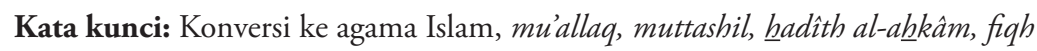

\section{Introduction}

The assessment of Shahîh al-Bukhârî, the work of al-Bukhârî (d. 256/870), as the most shabîh book of hadith among the existing hadith books in the Sunni community, has been debated. Among the problems contained in this book are related to the connection of sanad (chain of narrators) found in a number of places. ${ }^{1}$ Al- $\underline{\text { Humaydî }}$ (d. 219/834) al-Dâruquthnî (d. 385/995), Ibn Hazm (d. 456/1064), al-Ghassânî (d. 498/1105), al-Mâzarî (d. 536/1141), and Ibn al-'Arabî (d. 543/1148) were the scholars who had highlighted sanad continuity contained in the book. However, subsequent scholars, such as Ibn al-Shalâh (d. 643/1245), alNawawî (d. 676/1277) and Ibn Hajar (d. 852/1449) have given answers to the critics, ${ }^{2}$ or even to anyone who questions the problems in Shabît $\underline{\underline{h}}$ al-Bukhârî.

Among the problems of asânîd (plural form of the sanad), contained in Shabîh al-Bukhârî, is the existence of the al-sanad al-mu'allaq, such as the narration of $\underline{h} a d \hat{t} t h$ which is discussed in this article. In Sha $\underline{h} \underline{\hat{h}} \underline{\underline{h}}$ al-Bukhârî, the hadîth is narrated by al-Bukhârî in Kitâb al-îmân, Bâb Husn Islâm al-Mar', using the phrase "Mâlik said" at the beginning of sanad. ${ }^{3}$ While al-Bukhârî (d. 256/870) never met Mâlik (d. 179/795), because of the difference in the thabaqah (the plural of which is thabaqât [generation]). It is the narration of hadîth in which Ibn $\underline{\text { Hazm questioned. }}{ }^{4}$

${ }^{1}$ Sa’d Fahmî Aḥmad Bilâl, Al-Sirâj al-Munîr Fî Alqâb al-Muhaddithîn (al-Riyâdh: Maktabat al-Tawbah - Dâr Ibn Hazm, 1993), p. 366; Ahmad 'Umar Hâshim, Qawầid Ushûl al-Hadîth (Bayrût: Dâr al-Kitâb al-'Arabî, 1984), p. 60.

${ }^{2}$ Jonathan Brown, The Canonization of Al-Bukhârî and Muslim: The Formation and Function of the Sunnî Hadîth Canon (Leiden: BRILL, 2007), pp. 291-99.

${ }^{3}$ Muhammad Ibn Ismầ̂l al-Bukhârî, Shah $\underline{h} \underline{h}$ Al-Bukhârî, ed. by Râid Ibn Shabrî Ibn Abî

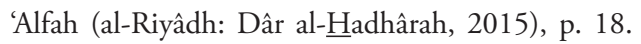

${ }^{4}$ Muhammad Ibn Aḥmad al-Aynî, 'Umdat al-Qârî̀, ed. by 'Abdullâh Mahmûd Muhammad 'Umar, 25 vols (Bayrût: Dâr al-Kutub al-'Ilmiyyah, 2001), I, pp. 391-92; Muhammad Ibn 
Ibn Hajar was a scholar who had commented on the narration of

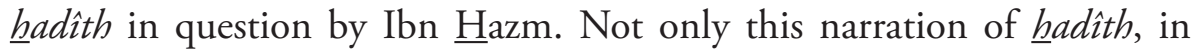
his work entitled Taghlìq al-Ta'lìq ${ }^{5}$, Ibn Hajar explains the problems of al-asânîd al-mu'allaqah contained in Shabîh al-Bukhârî. ${ }^{6}$ For anyone who wants to explore this issue, making this Ibn Hajar's work as the main reference is the right action. This is also the case with this article, where the discussion is referred to in the book. Thus, some parts of the discussion of this article are in the realm of verification for Ibn $\underline{\text { Hajar's }}$ work.

The urgency of expressing the validity of this hadîth status, among other things, is because the hadith has no other path in Shabîh alBukhârî, while al-Bukhârî mentions it with the jazm (certain) expression. Another thing why it is examined is that this hadith is found in several commentary books (kutub al-tafsîr). The position of hadith is as the source of tafsîr bi al-ma'thûr. ${ }^{7}$ This article tries to answer three questions, namely: (1) what is the status of the al-hadîth al-mu'allaq about the elimination of badness after someone converting to Islam in Shahîh $\underline{\underline{h}}$ al-Bukhârî? (2) How do the scholars give the opinion to the status of the $\underline{h} a d \hat{\imath} t h$ ? and (3) what are the implications of the status of $\underline{h} a d \hat{t} t h$ for Islamic works outside $\underline{\text { hadîth? }}$

\section{Al-Ahâdîth al-Mu'allaqah in Shahîh al-Bukhârî}

The term mu'allaq arises from the verb 'allaqa (to suspend; to hang). It is used because only the upper part of the chain of narrators

Yûsuf al-Kirmânî, Al-Kawâkib al-Darârî, ed. by Muhammad Muhammad 'Abd al-Lathîf, 25 vols (Bayrût: Dâr Ihyầ al-Turâth al-'Arabî, 1937), I, p. 167.

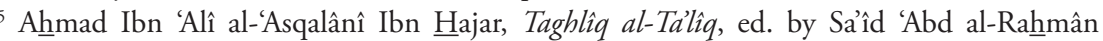
Mûsâ al-Qazaqî, 5 vols (Bayrût - Dimashq: al-Maktab al-Islâmî - Dâr 'Ammâr, 1985), I, p. 44.

${ }^{6}$ Muhammad 'Abd al-Hayy al-Laknawî, Zhafar al-Amânî bi-Sharh Mukhtashar al-Sayyid

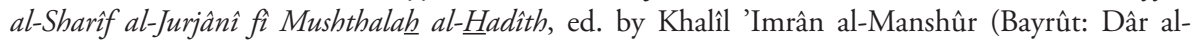
Kutub al-'Ilmiyyah, 1998), p. 86.

7 'Abd al-Rahmân Ibn Ibrâhîm al-Matrûdî, Al-A $\underline{h} r u f$ al-Qur'âniyyat al-Sab'ah (al-Riyâdh: Dâr 'Âlam al-Kutub, 1991), pp. 11-12; Muhammad Ibn 'Âshûr, Tafsîr al-'Adl wa al-I'tidâl

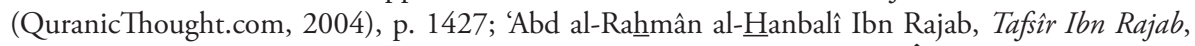
ed. by Thâriq Ibn 'Awdh al-Lâh Muhammad, 2 vols (al-Riyâdh: Dâr al-Âshimah, 2001), I, pp.

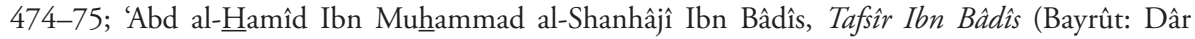
al-Kutub al-'Ilmiyyah, 2009), p. 52. 
remains giving it a hanging appearance. Technically, it means a hadîth with an isnâd from the beginning of which one narrator or more is deleted, ${ }^{8}$ missed, shortened, ${ }^{9}$ or omitted ${ }^{10}$ intentionally. This intention, as seen from Abû Dâwud's statement taraktu asânîdahâ li al-ikhtishâr (تركت أسانيدها للاختصار), is only for summarizing or shortening the chain of narrators. ${ }^{11}$ Generally, al-A $\underline{h} \hat{a} d \hat{\imath} t h$ al-mu'allaqah is categorized dha'îf (weak) and rejected automatically. The cause is one of the requirements of authenticity is missing. However, if they are narrated in hadith works in which the authors spent great efforts to include al-abâdìth al-shabîhah only, the narrations are acceptable.

The mu'allaq narrations in Shahîh al-Bukhârî are many ${ }^{12}$ even abound. ${ }^{13}$ More or less, the number were suspected of being mu'allaq reached 1341 hadîths. ${ }^{14}$ The great hadîth scholar, like Ibn Hajar, as mentioned in the introduction section, wrote two works for tracking down all the narrations of mu'allaq in Shahîh al-Bukhârî, namely: (1) Special Chapter in Hady al-Sârî̀ ${ }^{15}$ and (2) Taghlîq at-Ta lìqi. ${ }^{16}$ The result, of the 1341 hadiths that were suspected of being muallaq, only $160^{17}$ or 161 were truly mu'allaq. ${ }^{18}$

${ }^{8}$ Abu Ameenah Bilaal Philips, Ushool Al- Hadeeth: The Methodology of Hadith Evaluation (Riyadh: International Islamic Publishing House, 2007), p. 65.

${ }^{9}$ Sani Salih Mustapha, Sciences of Hadith Literature (Wiltshire: Paragon Publishing, 2017), p. 184.

${ }^{10}$ Fiazuddin Shuayb, "Who's Better than God to Rule?" - An Inquiry into the Formation of the First Islamic State (622-32 CE)' (University of California, 2012), p. x <https://escholarship. org/uc/item/87q494b4>; Abû 'Amr 'Uthmân Ibn 'Abd al-Rahmân Ibn al-Shalâh al-Shahrazûrî,

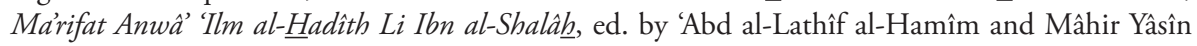
al-Fahl (Bayrût: Dâr al-Kutub al-'Ilmiyyah, 2002), pp. 92-93.

${ }^{11}$ Sulaymân Ibn al-Ash'ath al-Sijistânî Abû Dâwud, Sunan Abî Dâwud, ed. by Râid Ibn Shabrî Ibn Abî 'Alfah (al-Riyâdh: Dâr al-Hadhârah, 2015), p. 616.

${ }^{12}$ Philips, p. 65.

${ }^{13}$ Mustapha, p. 184.

${ }^{14}$ Ibn Maqshad al-'Abdalî, al-Qâdhî: 'Alâ Ta'lìâât al-Bukhârî (Dâr Nûr al-Yaqîn, 2012), p. 13.

${ }^{15}$ Mohammad Fadel, 'Ibn Hajar's Hady al-Sârî: A Medieval Interpretation of the Structure

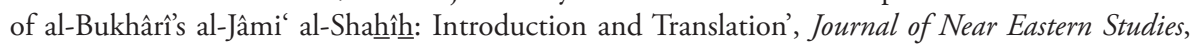
54.3 (1995), 161-97; Aḥmad Ibn 'Alî al-'Asqalânî Ibn Hajar, Hady al-Sârî Muqaddimat Fath al-Bârî, ed. by 'Abd al-Rahmân b. Nâshir al-Barrâk and Abû Qutaybah Nazhr Muhammad alFâriyâbî (al-Riyâdh: Dâr Thayyibah, 2005), pp. 29-174.

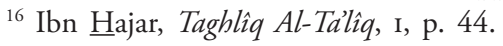

${ }_{17}$ al-Abdalî, p. 13.

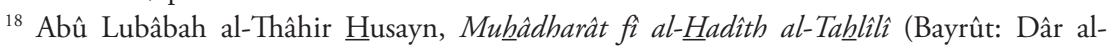
Gharb al-Islâmî, 2004), p. 172. 


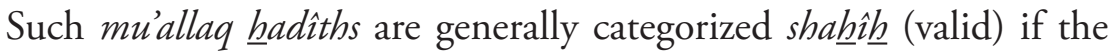
hadîth is narrated using active voice verbs. The kalimah (words) rawâa (he narrated); qâla (he said); thakara (he mentioned) and so on, indicated the narrations are sha $\underline{h} \underline{\underline{h}}$ (valid). On the other hand, if they are narrated using the passive voice, like ruwiya (it was narrated); qîla (it was said); thukira (it was mentioned), their status is uncertain. Some of them may be shahîh $\underline{h}$ (valid), others hasan (fair) and yet others dha'îf (weak). ${ }^{19}$ However, the weak narrations are not excessively weak. The classification is based due to their presence in these books in which the authors sought to compile only authentic hadiths. ${ }^{20}$ It should be noted, however, that those hadiths narrated in the passive voice due to weakness, may have authentic chains which al-mudawwin (codifier), like al-Bukhârî, did not come across ${ }^{21}$.

Based on all of these expressions, it is determined that the person to whom al-Bukhârî ascribed the hadîth, is spoke and related, as said by Abû Ja'far Ibn Hamdân al-Naysabûrî. These are the narrations in the form of al-'ardh (presentation) and al-munâwalah (transference). ${ }^{22}$ Thus, to ascertain or verify the qualifications of whether the hadith of elimination of a person's badness after someone converts to Islam is mu'allaq (suspended) or not, tracing is feasible.

\section{Takhrîj al-Hadîth for Evaluating the Narrations}

This research was conducted using a special literary study of hadith research, which is called takhrîj al- $\underline{h} a d i \hat{t} h$. It means editing, compositing, selecting, and correcting of the $\underline{h}$ adîth from the original sources. Another meaning of takhrîj al-badîth is tracing the hadith back to its original sources, explaining and evaluating of the sources of a $\underline{\text { hadit }} h^{23}$. The next step is to reexplain the degree of the hadith (either asânid [chains of

\footnotetext{
${ }^{19}$ al-Shahrazûrî, p. 93; Hâshim, p. 60; Philips, p. 65.

20 'Abdalhâdî al Fadhlî, Introduction to Hadîth (London: ICAS Press, 2011), p. 13.

${ }^{21}$ Philips, p. 65.

22 al-Shahrazûrî, p. 149.

${ }^{23}$ Adam Gacek, The Arabic Manuscript Tradition: A Glossary of Technical Terms and Bibliography, Handbuch Der Orientalistik = Handbook of Orientalistik. Section One, the Near and Middle East, v. 58 (Leiden ; Boston: Brill, 2001), p. 39.
} 
narrators] or mutûn al-hadîth [texts] if necessary. ${ }^{24}$ This article uses the works of al-Mizzî (d. 742/[1341/1342]), al-Dhahabî (d. 748/1348) and Ibn Hajar (d. 852/1449) and so forth, as a mine of information related to asanid (chains of transmissions) and the biographical information of each al-ruwâh of the narration of hadith under study.

Therefore, several steps must be taken in the use of takhrîj al- $\underline{\text { aditth }}$ as a research method, both manually and electronically. Even for the electronic method, today, it is divided into two, namely: off-line and on-line electronic methods. With these steps, the researcher can choose the right and easy method in referring to the researched hadith. When choosing the manual method, researchers refer to the method that al-Thahhân'25 and Ibn 'Abd alHâdî̀ ${ }^{26}$ offer as follows: (1) By knowing the companions or the first narrator who narrated the hadith. (2) By knowing the first pronunciation of the matn (texts). (3) By knowing the matn pronunciation which is used a little. (4) By knowing the subject matter of hadith in question or part of it, if it contains several subjects. (5) By examining the state of the hadith in an integrated manner, both in terms of Sanad and in terms of Matan. Of the five methods, this article chooses the second method $^{27}$ and third method ${ }^{28}$ to trace the existence of $\underline{h} a d \hat{t} t h$ about the elimination of a person's badness after someone converts to Islam, outside of Shah $\underline{\hat{h}} \underline{\underline{h}}$ al-Bukhârî.

When choosing the off-line electronic method, the researcher can use and select the application via a particular Compact Disk that is already installed on each personal computer (PC) /Laptop available. As for the on-line electronic method, researchers can directly track the hadîth through internet facilities by visiting existing portals, in which

${ }^{24}$ Mahmûd. al-Thahhân, Ushûul al-Takhrîj Wa-Dirâsat al-Asânîd (al-Qâhirah: Dâr al-Kutub al-Salafìyyah, 1982), p. 34.

${ }^{25}$ Mahmûd. al-Thahhân, Ushûll Al-Takhrîj Wa-Dirâsat al-Asânîd (al-Qâhirah: Dâr al-Kutub al-Salafiyyah, 1982), p. 35.

26 'Abd al-Muhdî ibn 'Abd al-Qâdir Ibn 'Abd al-Hâdî, Thuruq Al-Takhrîj Ha Qâhirah: Dâr al-I'tishâm, 1987), p. 24.

${ }^{27}$ Jalâl al-Dîn al-Suyûthî, Al-Jâmi“ al-Shaghîr Fî̀ A Al-Saghîr. (Bayrût: Dâr al-Kutub al-'Ilmîyah, 2004), p. 33.

${ }^{28}$ Arent Jan Wensinck, Johan Peter Mari Mensing, and Jan Brugman, Al-Mu'jam alMufahras Li Alfâzh al-Hadîth al-Nabawî: 'an al-Kutub al-Sittah Wa 'an Musnad al-Dârimî̀ Wa

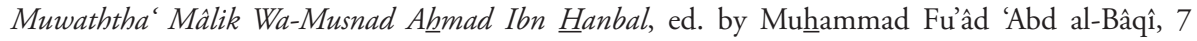
vols (Leiden: Brill, 1936), II, p. 518. 
the information related to the hadith under study is provided. Using this method, this article managed to trace the existence of $\underline{h}$ adîth about the elimination of a person's badness after converting to Islam, outside of

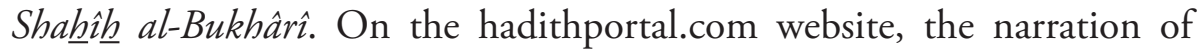
the hadîth was found in al-Mu'jam li Ibn al-A'rabî and Sunan al-Nasâî. ${ }^{29}$

In the context of hadîth research, Ibn al-Shalâh al-Shahrazûrî (d. 643/1245) presents the technical procedures of evaluating hadith by definition: ${ }^{30}$

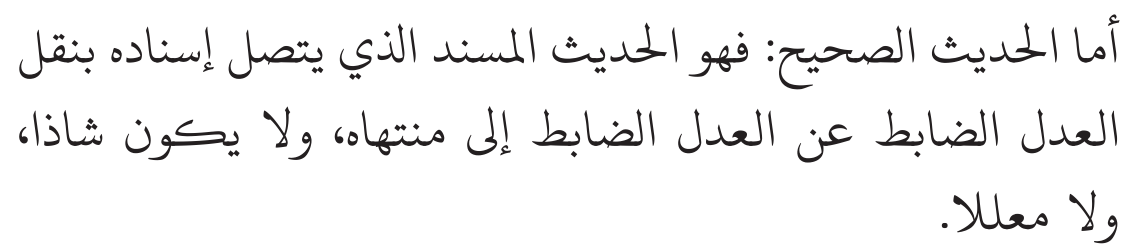

The valid hadith is a "supported" hadith (al-musnad [the chain of narration goes back to the Prophet]), the isnâd of which coheres continuously through the transmission of one upright (al-muttashil) and al-'adl (person of religious probity) and al-dhabth (accurate person) from another up to its point of termination. The valid hadith can be neither "anomalous" (shadhdh) nor "defective" (mu'allal). ${ }^{31}$

From the definition above, there are six conditions in evaluating hadîth, namely: (1) al-musnad and (2) muttashil are the first two condition in which related to the chain of narrations; (3) al-'adl and (4) al-dhabth are the second two condition in which related to the narrators; and avoid from (5) shudhudh and (6) illah are the last two condition that related to the matn (text) ${ }^{32}$, but not infrequently also related to the chain of narrations and narrators. ${ }^{33}$

${ }^{29}$ hadith portal, 'Jâmi' al-Sunnah Wa Shurûhuhâ', Jâmi' al-Sunnah Wa Shurûhuhâ, 2019 <https://www.hadithportal.com/> [accessed 17 December 2019].

${ }^{30}$ al-Shahrazûrî, p. 79.

${ }^{31}$ Cf., Ghassan Abdul Jabbar, 'The Classical Tradition', in The Wiley Blackwell Concise Companion to the Hadith, ed. by Daniel W. Brown, The Wiley Blackwell Companions to Religion (Hoboken, NJ: John Wiley \& Sons, Inc, 2019), pp. 15-38 (p. 20).

${ }^{32}$ Ghassan Abdul Jabbar, 'The Classical Tradition', in The Wiley Blackwell Concise Companion to the Hadith, ed. by Daniel W. Brown, The Wiley Blackwell Companions to Religion (Hoboken, NJ: John Wiley \& Sons, Inc, 2019), pp. 15-38 (p. 20).

${ }^{33}$ Abû Sufyân Mushthafâ Bâhû, Al-Illah Wa Ajnâsuhâ inda al-Munaddithîn (Thanthâ: 


\section{Al-Mashâdir al-Ashliyyah (The Original Sources)}

Based on the results of tracking carried out, the existence of the narration of hadith about the removal of a person's badness after converting to Islam is found in three books in the category of al-mashâdir al-ashliyyah. The three books are: (a) Shabîh al-Bukhârî of al-Bukhâri ([Abû 'Abd Allâh Muhammad ibn Ismâ'îl ibn Ibrâhîm ibn al-Mughîrah ibn Bardizbah al-Ju'fî al-Bukhârî] d. 256/870); (b) Sunan al-Nasầ̂ of al-Nasâî ([Abû 'Abd al-Rahmân Aḥmad ibn Shu'ayb Ibn Alî Ibn Sînân al-Nasâî] d. 303/915); and (c) al-Mujjam li Ibn al-A'râbî of Ibn al-A'râbî ([Abû Sa'îd Ahmad Ibn Muhammad Ibn Ziyâd Ibn Bishr Ibn al-A'râbî]] d. 340/951). In Shahîh al-Bukhârî, the narration is found in Kitâb alImân; Bâb Husn Islâm al-Mar'. ${ }^{34}$ In Sunan al-Nasầ, the narration is found in Kitâb al-Îmân; Bâb Husn Islâm al-Mar.'. ${ }^{35}$ And in al-Mu'jam li Ibn al-A'râbî, the narration is found in Mujam al-Mubammadiyinn. ${ }^{36}$

\section{The Book of Shahîh al-Bukhârî}

In Arabic, the title of the book is الجامع المسند الصحيح المختصر من أُمور المبحل

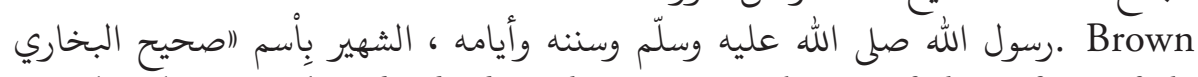
translated it to The Abridged Authentic Compilation of the Affairs of the Messenger of God, his Sunna and Campaigns ${ }^{37}$. This work is considered the greatest work of al-Bukhari and estuary of the application of the method of criticism of hadith and legal vision. This book contains various legal topics, rituals, and methodological conclusions of the narration,

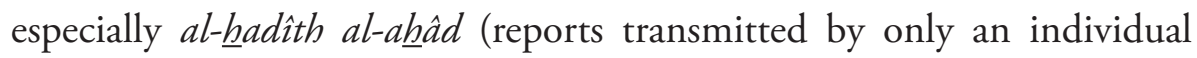
or few chains of narration) in law. Brown also alludes to traditions that do not mention the direct source of al-Bukhârî (called ta'lîq or mu'allaq)

Dâr al-Dhiyầ, 2005), p. 243.

${ }^{34}$ al-Bukhârî, p. 18.

${ }^{35}$ Ahmad Ibn Shu'ayb Ibn 'Alî Ibn Sinân al-Nasâî, Sunan Al-Nasầ̂, ed. by Râid Ibn Shabrî Ibn Abî 'Alfah (al-Riyâdh: Dâr al-Hadhârah, 2015), p. 673.

${ }^{36}$ Ahmad Ibn Muhammad Ibn Ziyâd Ibn A'râbî, Al-Mujjam Li Ibn al-A'râbî, ed. by 'Abd

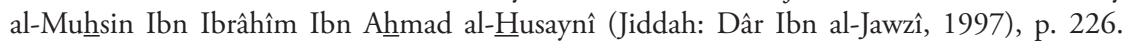

${ }^{37}$ Jonathan Brown, The Canonization of Al-Bukhari and Muslim: The Formation and Function of the Sunnihadith Canon., ed. by Wadad Kadi and Rotraud Wielandt (Leiden; Boston: Brill, 2007), p. 69. 
or reports from the Companions of the Prophet, to explain the report that al-Bukhari mentioned his direct source ${ }^{38}$, in the book of a different chapter or another. ${ }^{39}$ In this article, the narration of hadith in Shab $\underline{\hat{h}} \underline{\underline{h}}$ al-Bukhârî under study is:

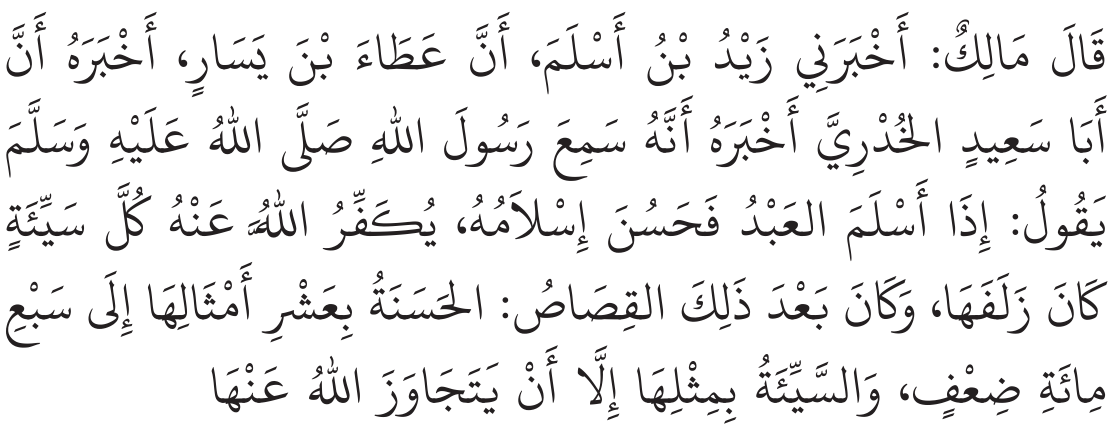

(Al-Bukhâri said that) Malik said: "Zayd Ibn Aslam has told me that

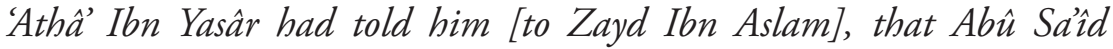
al-Khudrî had told him [to 'Athâ' Ibn Yasâr] that he [Abûu Sa'îd alKhudrî] was has heard the Messenger of Allâh [pbuh] said: "If someone converts to Islam, such that his (her) Islam is good, then for him [her], Allahh will erase every bad deed that he [or she] did before; then after that will come the reckoning; each good deed will be rewarded ten times up to seven hundred times; and each bad deed will be recorded as it is, unless Allâh forgives it. "’o

\section{The Book of Sunan al-Nasâî}

There are four main compilations in which the subject matters are characterized according to the tradition prevalent at the time of the Prophet. One of them is Sunan al-Nasầ ${ }^{41}$; the most renowned of which al-Nasâî wrote. It is known as Sunan al-Nasầi or al-Mujtabâ (the Selected) which is a selecting and summarizing of al-Nasâîs book

${ }^{38}$ Brown, The Canonization of Al-Bukhari and Muslim, p. 69.

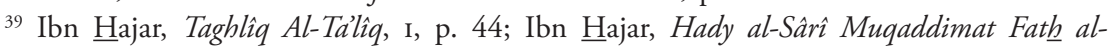
Bârî, pp. 29-174.

40 al-Bukhârî, p. 18.

${ }^{41}$ Yushau Sodiq, Insider's Guide to Islam (Bloomington: Trafford On-Demand Publishing, 2011), p. 159. 
of Hadith, al-Sunan Al-Kubrâ (the Big Traditions). ${ }^{42}$ In this article, the narration of hadîth in Sunan al-Nasầ̂ under study is:

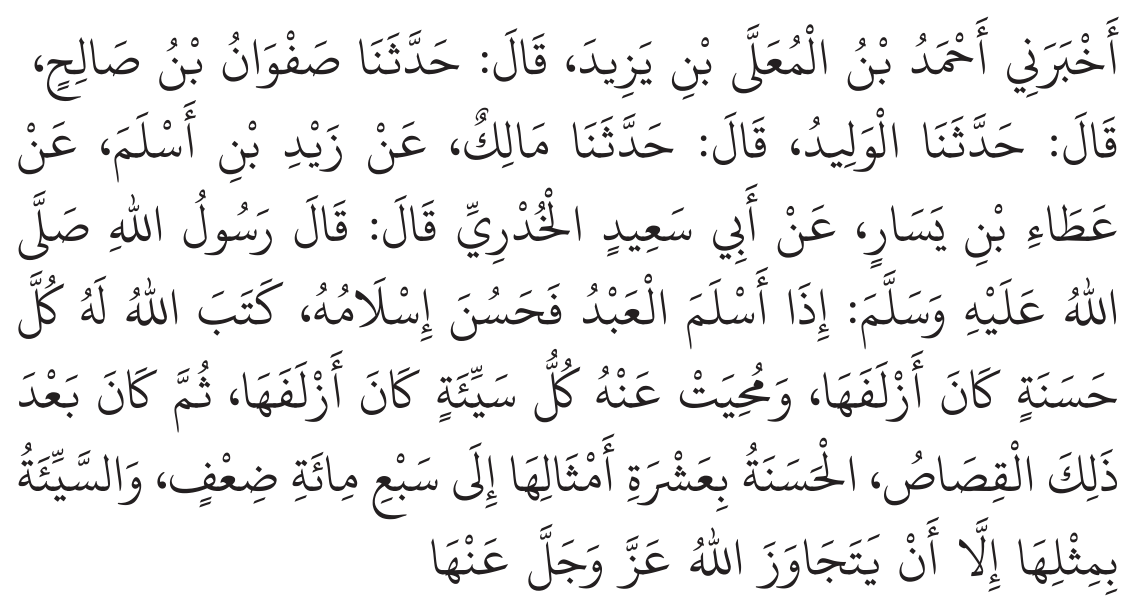

(Al-Nasầ̂ said that) Abmad Ibn al-Mu'allâ Ibn Yazîd has told me; he said that Shafwân Ibn Shâlih has told us; he (Shafwân Ibn Shâlih ) said that al-Walid has told us; he (al-Walid) said that Mâlik (Ibn Anas) has told us, from Zayd Ibn Aslam, from 'Athâ' Ibn Yasâr, from Abûu Saî̀ al-Khudrî (he said): that the Messenger of Allâh said: that The Messenger of Allâh [pbuh] said: "If someone converts to Islam, such that his (her) Islam is good, Allahh will decree reward for every good deed that he (she) did before, and every bad deed that he (she) did before will be erased. Then after that will come the reckoning; each good deed will be rewarded ten times up to seven hundred times; and each bad deed will be recorded as it is, unless Allahh, the Mighty and Sublime, forgives it." 43

\section{The Book of al-Mu'jam li Ibn al-A'râbî}

$\mathrm{Al}-\mathrm{Mu}$ 'jam, in the terminology of al-muhaddithîn, is a systematic book of hadith which is compiled based on the name of the codifier

${ }^{42}$ Nurkhalijah Siregar, 'Kitab Sunan An-Nasầ̂ (Biografi, Sistematika, dan Penilaian Ulama)', Hikmah, 15.1 (2018), 55-62.

43 al-Nasâî, p. 673. 
teacher ${ }^{44}$, in alphabetical order. ${ }^{45}$ Al-Mu'jam li Ibn al-A'râbî̀ is one example of a book of hadith written based on the name of the codifier teacher. It was the work of Muhammad Ibn Ziyâd Ibn Bishr Ibn al-A'râbî (d. 231/845), compiled by his son, Ahmad (d. 340/951). In this article, the narration of al-Mu'jam li Ibn al-A'râbî under study is:

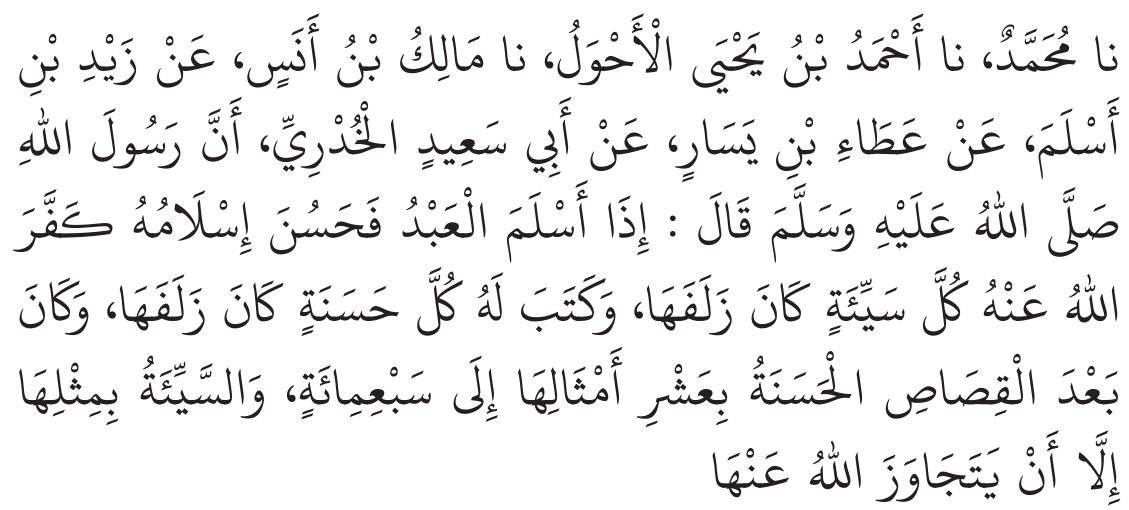

(Ibn al-A'râbî said that) Muhammad (Ibn 'Uthmân Ibn Abî Shaybah)

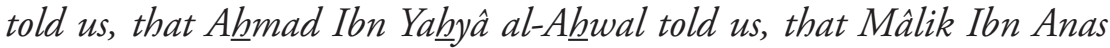
told us, (the report) from Zayd Ibn Aslam, from 'Athâ' Ibn Yasâr, from Abû Saî̀ al-Khudrî (he said): that the Messenger of Allâh [pbuh] said: "If someone converts to Islam, such that his (her) Islam is good, Allâh will erase every bad deed that he (she) did before; Allâh will decree reward for every good deed that he (she) did before; then after the reckoning; the good deed will be rewarded ten times up to seven hundred times; and each bad deed will be recorded as it is, unless Allâh forgives it." "น́

\section{Sanad Criticism}

In general, sanad is a series of names of the ruwât al-hadîth (badiths narrators/transmitters). ${ }^{47}$ They are the people who, because of

${ }^{44}$ Olzhas Mirzakhanovich Shayakhmetov, 'On the Metalanguage of Modern Arabic Lexicography’, Review of European Studies, 7.6 (2015), 209-2016 <https://doi.org/10.5539/res. v7n6p209>.

${ }^{45}$ al-Thahhân, p. 111.

${ }^{46}$ Ibn A'râbî, p. 226.

${ }^{47}$ Ibrâhîm Ibn 'Abdillâh al-Qâsimî, Taqrîb Ishthilâh al-Muhaddithîn min Ifhâm al-Thâlibîn 
their position, convey the narration of hadith (matn al-hadîth) from the previous narrator, and then pass it on to others who receive it. The majority of first people in receiving $\underline{\text { hadith }}$ are companions. ${ }^{48}$ The transmission was later continued to the followers and so forth, until to the hadìth codifiers (mudawwin) ${ }^{49}$. In this article, the hadìth codifiers are al-Bukhâri, al-Nasâî, and Ibn al-A'râbî.

To prove that each of these al-ruwâh met each other in the context of

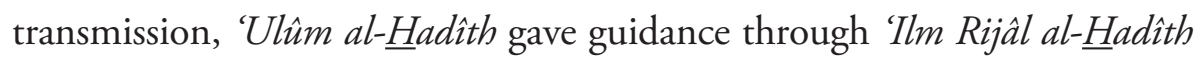
${ }^{50}$. In this science, it is explained how a hadith researcher can obtain certainty of the continuity of asânîd through biographical information or tarjamat al-ruwâh contained in the books of al-rijâl..$^{51}$ The books also providing the qualification of al-ruwâh in which the records of an element of al-jarh wa al-tádîl applied or reported. ${ }^{52}$ When they are described in a schematic construct, each sanad in this article can be described as follows:

\section{a. Al-Sanad of Shahîh al-Bukhârî}

There are four al-ruwâh in the sanad of Shabîh al-Bukhârî, namely: Mâlik Ibn Anas, Zayd Ibn Aslam, 'Athâ' Ibn Yasâr, and Abû Sarîd alKhudrî. In this chain of narration, al-Bukhârî did not meet Mâlik Ibn Anas.

(al-Qâhirah: Dâr al-Hilâl li al-Kutub al-Islâmiyyah, 1985), p. 16; Muwaffaq ibn 'Abd Allâh. Ibn 'Abd al-Qâdir, Tawthîq Al-Nushîsh Wa-Dhabthuhâ inda al-Muhaddithîn (Makkah al-Mukarramah: al-Maktabah al-Makkîyah, 1993), p. 9.

${ }^{48}$ Muhammad ibn Salâmah Qudhâ'î, A Light in the Heavens: Sayings of the Prophet Muhammad, trans. by Tahera Qutbuddin (New York: New York University, 2019), p. xxvii.

${ }^{49}$ William A. Graham, 'Traditionalism in Islam: An Essay in Interpretation', The Journal of Interdisciplinary History, 23.3 (1993), 495-522 <https://doi.org/10.2307/206100>.

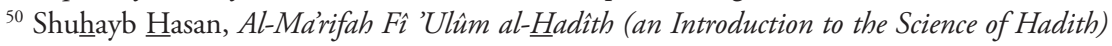
(al-Riyâdh: Dâr al-Salâm), p. 16.

${ }^{51}$ al-Thahhân, p. 157; Recep Sentürk, Narrative Social Structure: Anatomy of the Hadith Transmission Network, 610-1505 (California: Stanford University Press, 2005), p. 60.

${ }^{52}$ Abdul Jabbar, p. 20; Iftikhar Zaman, "The Science of "Rijâl" as a Method in the Study of Hadiths', Journal of Islamic Studies, 5.1 (1994), 1-34. 
Picture-1

Sanad of Shabîh al-Bukhârî

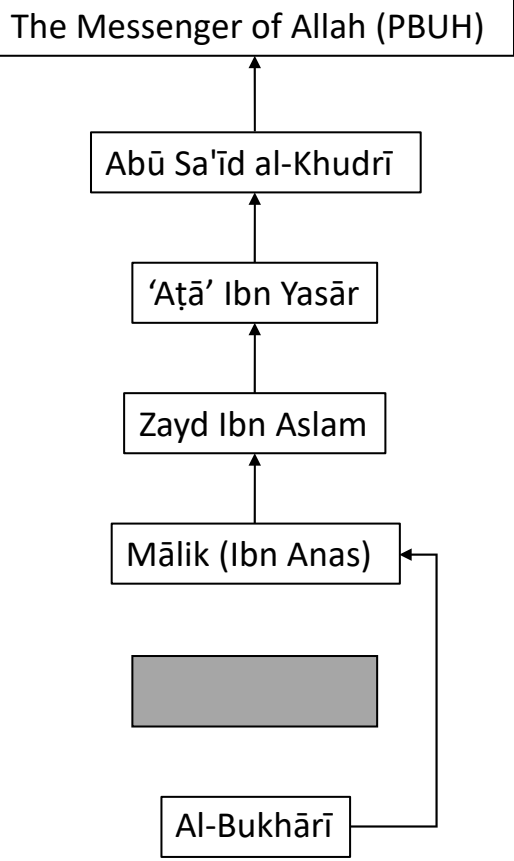

Brief information of each al-ruwâh in the above sanad can be seen in the following explanation:

(1) Mâlik Ibn Anas: Mâlik ibn Anas Ibn Mâlik Ibn Abû 'Âmir, alAshbahîi al-Humayrî, Abû 'Abdillâh, the early Tâbi' al-Tâbiîn (d. 179/795). He was very highly qualified ta'dîl (ra's al-mutqinîn; kabîr al-mutathabbitin). He received the narration of hadiths from scholars on his generation (thabâqât), including from Zayd Ibn Aslam. ${ }^{53}$

(2) Zayd Ibn Aslam: Zayd Ibn Aslam al-’Adawî al-Qurashî Abû Usâmah, middle Tabiîn (d. 136/754). He was highly qualified ta'dîl (thiqah;

53 Shams al-Dîn Abû 'Abdillâh Muhammad ibn Aḥmad al-Dimashqî al-Dhahabî, Siyar A'lâm al-Nubâlâ', ed. by Shu'ayb al-Arnâûth and Muhammad Na'îm al-'Arqasûsî, 25 vols (Bayrût: Muassasat al-Risâlah, 1982), viII, pp. 48-52; Jamâl al-Dîn Yûsuf Abû al-ㅂajajâj al-Mizzî, Tahdhîb Al-Kamâl Fî̀ Asmâ' al-Rijâl, ed. by Bashshâr 'Awwâd Mảrûf, 35 vols (Bayrût: Muassasat al-Risâlah,

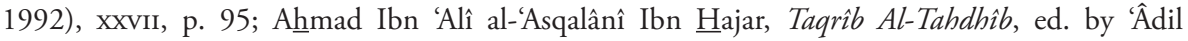
Murshid (Bayrût: Muassasat al-Risâlah, 1999), p. 449. 
âlim). He received the narration of hadîths from scholars on his generation (thabâqât), including from 'Athâ' Ibn Yasâr. ${ }^{54}$

(3) 'Athâ' Ibn Yasâr: 'Athâ' Ibn Yasâr al-Hilâlî Abû Muhammad, the early Tâbiîn (d. 103/721). He was highly qualified ta'dîl (thiqah, fâdhil; shâhib mawâizh wa ibâdah). He received a narration of badîths from scholars on his generation (thabâqât), including from a Companion of the Prophet, Abû Sa'îd al-Khudrî. ${ }^{55}$

(4) Abû Sa'îd al-Khudrî: Sa’ad Ibn Mâlik Ibn Sinân Ibn 'Ubayd alKhudrî al-Anshârî Abû Sa'îd. He was a Companion (Shahâabah) (d. $74 / 693)^{56}$.

Mâlik Ibn Anas as râwî (narrator/transmitter), who finished last before the codifier (al-Bukhâri), was known to have never met al-Bukhâri. In other words, al-Bukhâri never received the narration from him (from Mâlik Ibn Anas), because he never met. This is what later led to the assessment that the narration of hadîth in Sha hîh al-Bukhârî is mu'allaq.

\section{b. Al-Sanad of Sunan al-Nasâî}

There are seven narrators/transmitters (al-ruwâh) in the sanad of Sunan al-Nasâî. They are Ahmad Ibn al-Mu'allâ Ibn Yazîd, Shafwân Ibn Shâlih, al-Walîd, Mâlik Ibn Anas, Zayd Ibn Aslam, 'Athầ Ibn Yasâr and Abû Sarîd al-Khudrî. Of the seven al-ruwâh (narrators/transmitters) above, four are al-ruwâh of Shahîh al-Bukhârî. While in Sunan al-Nasâtî, sanad (chain of narration) continues from Mâlik Ibn Anas to al-Walîd,

${ }^{4}$ Shams al-Dîn Abû 'Abdillâh Muhammad ibn Ahmad al-Dimashqî al-Dhahabî, Siyar A'lâm al-Nubâlâ', ed. by Shu'ayb al-Arnâûth and Muhammad Na'îm al-'Arqasûsî, 25 vols (Bayrût: Muassasat al-Risâlah, 1982), v, pp. 316-17; Jamâl al-Dîn Yûsuf Abû alAl-Kamâl Fî Asmầ al-Rijâl, ed. by Bashshâr 'Awwâd Mảrûf, 35 vols (Bayrût: Muassasat al-Risâlah, 1992), x, p. 13; Ibn ㅂajar, Taqrîb Al-Tahdhîb, p. 162.

55 Shams al-Dîn Abû 'Abdillâh Muhammad ibn Aḥmad al-Dimashqî al-Dhahabî, Siyar A'lâm al-Nubâlâ', ed. by Shu'ayb al-Arnâûth and Muhammad Na'îm al-Arqasûsî, 25 vols (Bayrût: Muassasat al-Risâlah, 1982), Iv, pp. 448-49; Jamâl al-Dîn Yûsuf Abû alAl-Kamâl Fî̀ Asmầ al-Rijâl, ed. by Bashshâr 'Awwâd Mảrûf, 35 vols (Bayrût: Muassasat al-Risâlah,

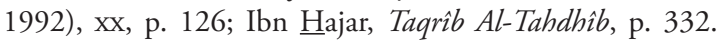

${ }^{56}$ Ahmad Ibn 'Alî al-'Asqalânî Ibn Hajar, Al-Ishâbah Fî̀ Tamyîz al-Shahâabah, ed. by 'Âdil Ahmad 'Abd al-Mawjûd and 'Alî Muhammad Mu'awwadh, 8 vols (Bayrût: Dâr al-Kutub al'Ilmiyyah, 1995), III, p. 65. 
Shafwân Ibn Shâlih and Ahmad Ibn al-Mu'allâ Ibn Yazîd and ends at al-Nasâî as the codifier of Sunan al-Nasầi.

Picture-2

\section{Sanad of Sunan al-Nasâî}

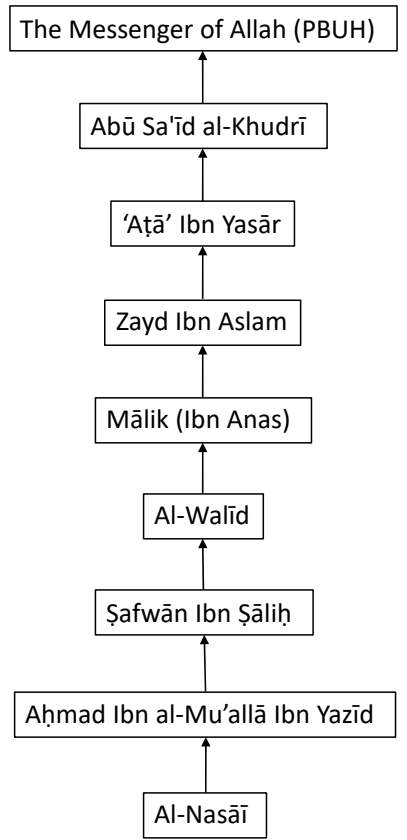

Brief information for the three al-ruwâh (narrators/transmitters) in Sunan al-Nasâî can be seen in the following explanation:

(1) Al-Walîd: al-Walîd Ibn Muslim Abû al-'Abbâs, middle Tâbi' alTâbiî̀n (d. 195). He was qualified tádîl (thiqah; kathîr al-tadlîs wa al-taswiyyah). He received the narration of hadîths from scholars on his generation (thabâqât) including Mâlik Ibn Anas. ${ }^{57}$

(2) Shafwân Ibn Shâliḥ: Shafwân Ibn Shâlih Ibn Shafwân Ibn Dînâr al-Thaqafî Abû 'Abd al-Mâlik, early Tâbi' al-Atbâ' (d. 239). He

${ }^{57}$ Shams al-Dîn Abû 'Abdillâh Muhammad ibn Ahmad al-Dimashqî al-Dhahabî, Siyar A'lâm al-Nubâlâ', ed. by Shu'ayb al-Arnâûth and Muhammad Na'îm al-'Arqasûsî, 25 vols (Bayrût: Muassasat al-Risâlah, 1982), Ix, pp. 211-20; Jamâl al-Dîn Yûsuf Abû al-Hajjầj al-Mizzî, Tahdhîb Al-Kamâl Fî̀ Asmầ al-Rijâl, ed. by Bashshâr 'Awwâd Màrûf, 35 vols (Bayrût: Muassasat al-Risâlah, 1992), xxxı, p. 88; Ibn Hajar, Taqrîb Al-Tahdhîb, p. 513. 
was qualified ta'dîl (thiqah; yudallis tadîs al-taswiyyah). He received the narrtion of hadiths from scholars on his generation (thabâqât) including al-Walîd Ibn Muslim. ${ }^{58}$

(3) Ahmad Ibn al-Mu'allâ Ibn Yazîd: Aḥmad Ibn al-Mu'allâ Ibn Yazîd al-Asadî Abû Bakr, Tâbi’ al-Atbâ' (d. 286). He was qualified middle ta'dîl (shadîq). He received the narration of hadìth from Shafwân Ibn Shâlih and continued it to al-Nasâi. ${ }^{59}$

The third position of al-ruwâh in Sunan al-Nasâî is considered as the "savior" of sanad in Shahîh al-Bukhâri in which considered muallaq (suspended). This is what then appears in several explanations, especially in Ibn Hajar's work, that all of al-asânîd al-mu'allaqah in Shahîh alBukhâri has supported by another chain, so that there is a connection to the asânîd (chains of narrators). ${ }^{60}$

\section{c. Al-Sanad of Al-Mu'jam li Ibn al-A'râbî}

In al-Mujjam li Ibn al-A'râbî, there are six al-ruwâh for the narration of hadith about the removal of a person's badness after entering to Islam. They are Muhammad Ibn 'Uthmân Ibn Abî Shaybah, Aḥmad Ibn Yahyâ al-Ahwal, Malik Ibn Anas, Zayd Ibn Aslam, 'Athâ’ Ibn Yasâr and Abû Sa'îd al-Khudrî. Similar to what is found in Sunan al-Nasầ̂, four people are al-ruwâh of Shahîh al-Bukhârî. The two narrators (al-râwiyân) in the book of al-Mu'jam li Ibn al-A'râbî are Muhammad Ibn 'Uthmân Ibn Abî Shaybah and Ahmad Ibn Yahyâ al-Ahwwal.

${ }^{58}$ Shams al-Dîn Abû 'Abdillâh Muhammad ibn Aḥmad al-Dimashqî al-Dhahabî, Siyar A'lâm al-Nubâlâ', ed. by Shu'ayb al-Arnâûth and Muhammad Na'îm al-'Arqasûsî, 25 vols (Bayrût:

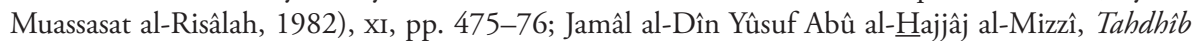
Al-Kamâl Fî Asmầ al-Rijâl, ed. by Bashshâr 'Awwâd Mảrûf, 35 vols (Bayrût: Muassasat al-Risâlah, 1992), XIII, p. 192; Ibn Hajar, Taqrîb Al-Tahdhîb, p. 218.

59 Shams al-Dîn Abû 'Abdillâh Muhammad ibn Ahmad al-Dimashqî al-Dhahabî, Târîkh Al-Islâm Wa Wafayât al-Mashâhîr Wa al-A'lâm, ed. by 'Umar 'Abd al-Salâm Tadmûrî, 53 vols (Bayrût: Dâr al-Kitâb al-'Arabî, 1991), xxi, pp. 88-89; Jamâl al-Dîn Yûsuf Abû al-Hajjââ al-Mizzî, Tahdhîb Al-Kamâl Fî̀ Asmầ' al-Rijâl, ed. by Bashshâr 'Awwâd Ma'rûf, 35 vols (Bayrût: Muassasat al-Risâlah, 1992), I, pp. 201-2; Ibn Hajar, Taqrîb Al-Tahdhîb, p. 24.

${ }^{60}$ Ibn Hajar, Hady al-Sârî Muqaddimat Fath al-Bârî, pp. 29-174; Ibn Hajar, Taghlîq Al-Tàlìq, I, p. 44. 
Picture-3

Sanad of al-Mu'jam li Ibn al-A'râbî

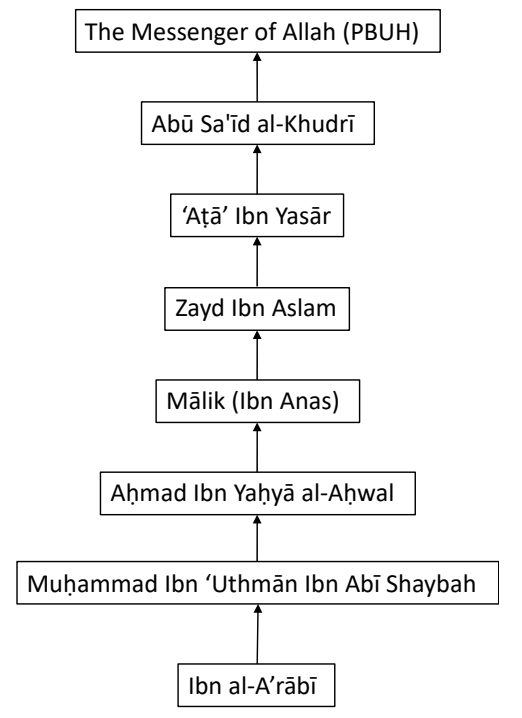

Brief information for these two al-râwiyân in al-Mujam li Ibn alA'râbî can be seen in the following explanation:

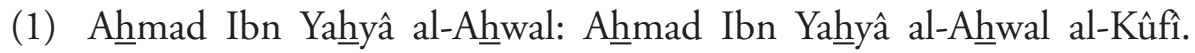
He was qualified al-jarh . Ibn Hibbân (d. 354/965) mentioned him in his book, Kitâb al-Thiqât, in which the narration is different and wrong. ${ }^{61}$ Al-Dâruquthnî mentioned Aḥmad Ibn Yahyâ alAhwal in qualified al-jarh (dha'îf), by repoting him in al-Dhu'afâ' wa al-Matrûkîn. ${ }^{62}$ The information from al- Dâruquthnî was later quoted by al-Dhahabî, ${ }^{63}$ Ibn al-Jawzî̀, ${ }^{64}$ Ibn Hajar, ${ }^{65}$ al-Wâdi $\hat{\imath},{ }^{66}$

${ }^{61}$ Abû Hâtim Muhammad Ibn Hibbân, Kitâb Al-Thiqât, ed. by Ibrâhîm Shams al-Dîn and Turkî Farhân al-Mushthafâ, 5 vols (Bayrût: Dâr al-Kutub al-'Ilmiyyah, 1998), v, p. 16.

62 'Alî Ibn 'Umar Ibn Ahmad al-Dâruquthnî, Al-Dhu'afâ Wa al-Matrûkîn, ed. by Muhammad Ibn Luthfî al-Shabbâgh (Bayrût-Dimashq: al-Maktab al-Islâmî, 1980), p. 70.

${ }^{63}$ Shams al-Dîn Abû 'Abdillâh Muhammad ibn Aḥmad al-Dimashqî al-Dhahabî, Mîzân Al-I'tidâl Fî Naqd al-Rijâl, ed. by 'Alî Muhammad al-Bajâwî, 4 vols (Bayrût: Dâr al-Mảrifah, 1963), I, p. 162.

${ }^{64}$ Jamâl al-Dîn 'Abd al-Rahmân Ibn al-Jawzî, Al-Dhu'afâ Wa al-Matrûkîn, ed. by Abû al-Fidâ' 'Abdullâh al-Qâdhî, 2 vols (Bayrût: Dâr al-Kutub al-'Ilmiyyah, 1986), I, p. 92.

${ }^{65}$ Ah̆mad Ibn 'Alî al-Asqalânî Ibn $\underline{H}$ ajar, Lisân al-Mîzâan, ed. by 'Abd al-Fattâh Abû Ghuddah and Salmân 'Abd al-Fattâh Abû Ghuddah, 10 vols (Bayrût: Dâr al-Bashâir al-Islâmiyyah, 2002), I, p. 690.

${ }^{66}$ Muqbil Ibn Hâdî al-Wâdi'î, Tarâjum Rijâl Al-Dâruquthnî Fî Sunanihî al-Ladhî Lam 
and al-Muslimi et al. ${ }^{67}$

(2) Muhammad Ibn 'Uthmân Ibn Abî Shaybah: This biography of râwî is revealed by al-Khathîb al-Baghdâdî, ${ }^{68}$ al-Dhahabî, ${ }^{69}$ and Ibn Hajar. ${ }^{70}$ The obtained information of the râwî divided into two categories. There are two groups of scholars who have evaluated the râwi. The first group classifies him as a trusted person, while the second accuses him of being a liar. ${ }^{71}$

The scholars who are in the first group in which classified Muhammad Ibn 'Uthmân Ibn Abî Shaybah as a trusted person are: Ibn al-Munâdî (d. 256/869), Shâlih Jazarah (d. 293/906), 'Abdân al-Ahwâzî (d. 306/918), Abû Ahmad Ibn 'Adi (d. 365/976), Ibn Hibbân (d. 354/965), al-Khathîb (d. 463/1071), al-Dhahabî (d. 748/1348), and Ibn Hajar (d. 852/1448).72 al-Khathîb al-Baghdâdî said of him (Muhammad Ibn 'Uthmân Ibn Abî Shaybah): "He knew many hadiths and used them to inform widely. He was a knowledgeable and understanding person." ${ }^{33}$ Al-Dhahabi said: "He (Muhammad Ibn 'Uthmân Ibn Abî Shaybah) was a person who was familiar with hadiths and narrators. ${ }^{74} \mathrm{He}$ composed useful works. "The conclusions of al-Khathîb al-Baghdâdî and al-Dhahabî were then quoted by Ibn Hajar. ${ }^{75}$

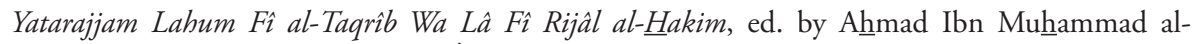
Qadasî and others (Shan'â:: Dâr al-Âthâr; Muassasat al-Rayyân), pp. 129-30.

${ }^{67}$ Muhammad Muhdî al-Muslimî and others, Mawsî̀at Aqwâl al-Dâruquthnî Fî̀ Rijâl al-Hadîth Wa 'llalihî̀ (Bayrût: Âlam al-Kutub, 2001), p. 104.

${ }^{68}$ Al-Khathîb al-Baghdâdî, Tárîkh Madînat Al-Salâm, ed. by Bashshâr 'Awwâd Mảrûf, 17 vols (Bayrût: Dâr al-Gharb al-Islâmî, 2001), III, pp. 42, 47.

69 Shams al-Dîn Abû 'Abdillâh Muhammad ibn Ahmad al-Dimashqî al-Dhahabî, Mîzân Al-I'tidâl Fî̀ Naqd al-Rijâl, ed. by 'Alî Muhammad al-Bajâwî, 4 vols (Bayrût: Dâr al-Mảrifah, 1963), III, p. 642; Shams al-Dîn Abû 'Abdillâh Muhammad ibn Aḥmad al-Dimashqî al-Dhahabî, Siyar A'lâm al-Nubâlâ', ed. by Shu'ayb al-Arnâûth and Muhammad Na'îm al-'Arqasûsî, 25 vols (Bayrût: Muassasat al-Risâlah, 1982), xIv, p. 21.

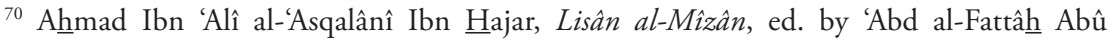
Ghuddah and Salmân 'Abd al-Fattâh Abû Ghuddah, 10 vols (Bayrût: Dâr al-Bashâir al-Islâmiyyah, 2002), v, p. 280.

${ }^{71}$ Umm 'Abdillâh al-Mîsâwî, 'Abû Jảfar Ibn Abî Shaybah (Nahw 210-297 H)', Aqîdat alSalaf al-Shâlih 2009 <http://as-salaf.com/article.php?aid=31\&lang=ar> [accessed 21 December 2019].

72 al-Mîsâwî.

73 al-Baghdâdî, III, pp. 42, 47.

74 al-Dhahabî, III, p. 642; al-Dhahabî, xıv, p. 21.

${ }^{75}$ Ibn $\underline{\text { Hajar, v, p. } 280 .}$ 
While the scholars who are in the second one are: Ibn 'Uqdah (d. 332/944), 'Abd al-Ghanî b. Sa'îd al-Azdî (d. 409/1018 [refered Ibrâhîm b. Ishâa al-Shawwâf), Dâwud Ibn Yahyyâ al-Dihqân, 'Abd al-Raḩmân b. Yûsuf b. Kharâsh (d. 283/896), Muhammad b. Abdullâh al- $\underline{\text { Hadhrâmî }}$

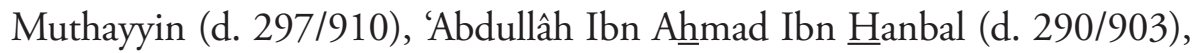
Ja'far Ibn Muhammad Ibn Abî 'Uthmân al-Thayâlîsî (d. 283/896), 'Abdullâh Ibn Ibrâhîm Ibn Qutaybah, Muhammad Ibn Ahmad al-'Adwi, Muhammad Ibn 'Ubayd Ibn ㅂammâd (refered Ja'far Ibn Hudhayl), and Mûsâ Ibn Ishâq al-Anshârî (d. 296/909).

This accusation of lying is only transmitted by Ibn 'Uqdah (d. 332/944) and no one else. People are different about him; some are agreed with him and others disagree. Al-Harawî and Ibn al-Harawânî judged Ibn 'Uqdah with negative judgment. ${ }^{76}$ Hamzah Ibn Yûsuf reported Abû Bakr Ibn 'Abdân as a scholar who rejected Ibn Uqdah's criticism. So, criticism is questionable. ${ }^{77}$ His criticism based on the difference in schools was rejected in which because Ibn 'Uqdah was Zaydî, and Ibn Abî Shaybah was a Sunni. Intolerance among adherents of the schools occurred at al-Kufa in $270 \mathrm{AH}$. A number of hadiths narrated by each adherent of the schools are not accepted by each other. In the view of Ibn 'Adî (d. 332/943), the right decision is that criticism from both of them against one another should not be accepted. ${ }^{78}$ This report is also agreed by al-Dhahabî, ${ }^{79}$ and Ibn $\underline{\text { Hajar }} .^{80}$

In the dynamics of the different narrator's qualifications above, there is no explanation of the scholars regarding the classification of sanad in al-Mu'jam li Ibn al-A'râbî. Almost all commentators of Shahîh al-Bukhârî refer to Sunan al-Nasâî, because of its validness (shahîh $\underline{\text { }}$ ), as its "savior", without referring to Ibn al-A'râbî. In various Shûrûhât of Shahîh alBukhârî itself even revealed other "savior" paths from al-Harawî, alIbn Sufyân, al-Bazzâr, al-Ismâliî, al-Bayhaqî, and al-Dâruquthnî; it all

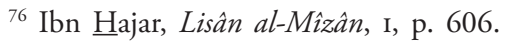

77 al-Baghdâdî, III, pp. 42, 47.

78 al-Baghdâdî, III, pp. 42, 47.

79 al-Dhahabî, III, p. 642; al-Dhahabî, xıv, p. 21.

${ }^{80}$ Ibn $\underline{\text { Hajar, v, p. } 280 .}$
} 
comes down to Mâlik Ibn Anas. Besides that, Ibn Hajar finally quoted al-Khathîbıs opinion about the certainty of this hadîth's narration, even though the continuity of his sanad, as al-Bazzâr said, was only on the solitude of the Mâlik ibn Anas.

\section{Picture-4}

Sanad Combined of Shahîh al-Bukhârî, Sunan al-Nasâî, and al-Mu'jam li Ibn al-A'râbî

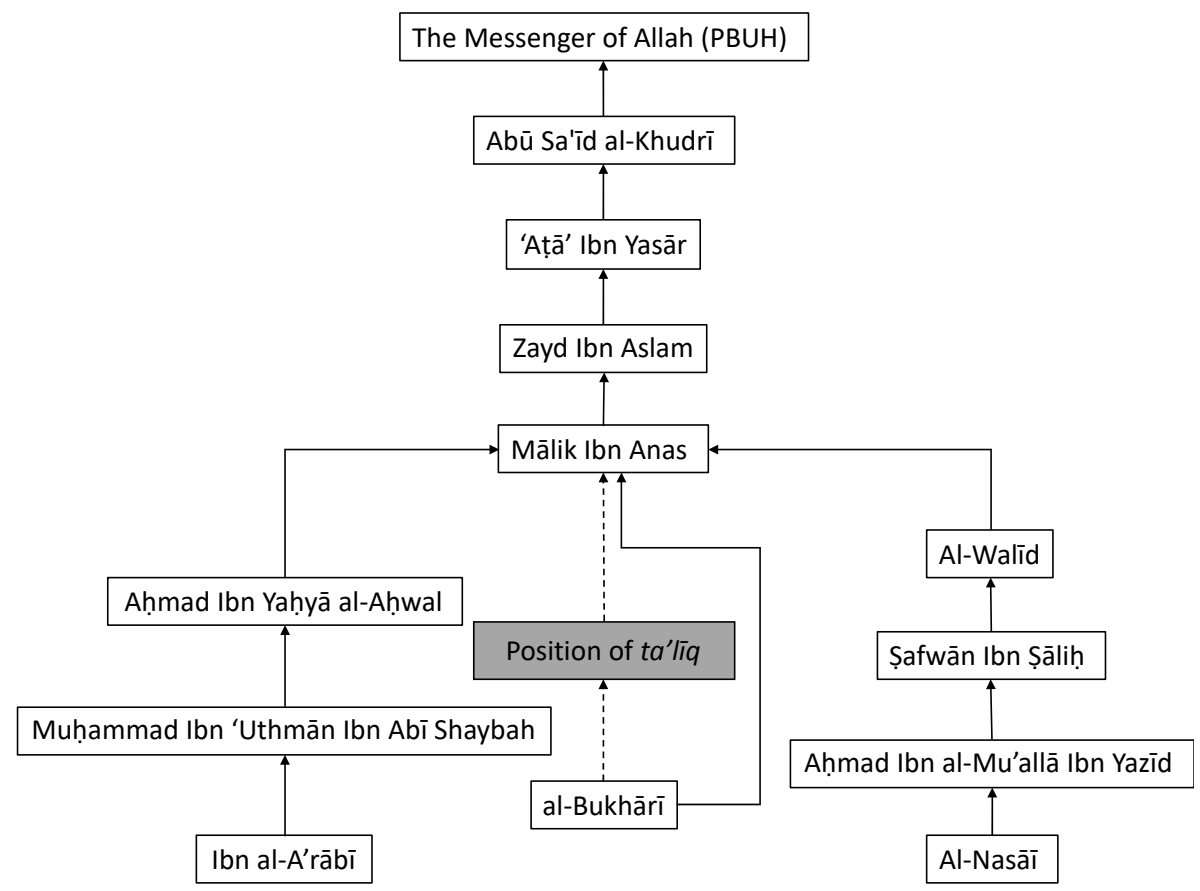

From the above explanation, it appears that the issue of the connection of sanad only lies in Shahîh al-Bukhârî. Except for Ibn Hazm, ${ }^{81}$ the majority of scholars agree that the sanity of this sanad in Shahîh al-Bukhârî was saved, either by Sunan al-Nasâîs sanad or in the explanation given in the Shûrûhât (Commentaries) of Shahîh al-Bukhârî. ${ }^{82}$

81 al-Aynî, I, pp. 391-92; al-Kirmânî, I, p. 167.

82 Aḥmad Ibn 'Alî al-'Asqalânî Ibn Hajar, Fath Al-Bârî, ed. by Shu'ayb al-Arnaûth and 'Âdil Murshid, 24 vols (Bayrût: Muassasat al-Risâlah, 2013), III, pp. 211-12. 


\section{Matn al-Hadîth and Shurûhât}

From the results of tracking carried out, there is no difference in the text of mutûn al-hadith which is fundamental in each of al-mashâdir al-ashliyyah. Therefore, in this mutûn al-hadìth analysis, the discussion is not carried out separately. Even, the difference only lies in the form of vocabulary used. Thus, this mutûn al-hadith analysis is in one unified explanation for each of the al-mashâdir al-ashliyyah.

Likewise, the sharh for mutûn al-hadîth, except for al-Mu'jam li Ibn al-A'râbî in which the shar $\underline{h}$ was not found, the works of shar $\underline{h}$ al-hadith, both for Shahîh al-Bukhârî and for Sunan al-Nasâî, all complement each other. Besides Ibn Hajar with his Fath al-Bârî, many of Shîrûhât of Shabîh al-Bukhârî, such as Ibn Baththâl (d. 449), ${ }^{83}$ al-Nawawî (d. 676), ${ }^{84}$ al-Kirmânî (d. 786), ${ }^{85}$ Ibn al-Mulaqqin (d. 804), ${ }^{86}$ al-Damâmînî (d. 827), ${ }^{87}$ al-Barmâwî (837), ${ }^{88}$ al-Aynî (d. 855), ${ }^{89}$ al-Suyûthî (d. 911), ${ }^{90}$ al-Qasthalânî (d. 923), ${ }^{91}$ al-Anshârî (d. 926) ${ }^{92}$ and Shûrûhât of Sunan alNasầ̂, such as Sunan al-Nasâî bi Syarh al-Hâfizh Jalâl al-Dîn al-Suyûthî̀ wa Hâshiyyat al-Imâm al-Sindî ${ }^{93}$ and al-Athyûbî, ${ }^{94}$ refer to the existence

83 'Alî Ibn Khalaf Ibn 'Abd al-Malik Ibn Baththâl, Shark $\underline{h}$ Shahîh $\underline{h}$ Al-Bukhârî Li Ibn Baththâl, ed. by Abû Tamîm Yâsir Ibn Ibrâhîm, 11 vols (al-Riyâdh: Maktabat al-Rushd, 2003), I, p. 98.

${ }^{84}$ Abû Zakariyyâ Yahyâ ibn Sharaf al-Nawawî, Al-Talkhîsh Sharh al-Jâmi' al-Shahâh $\underline{h}$, ed. by Nazhr Muhammad al-Fâriyâbî Abû Qutaybah (al-Riyâdh: Dâr Tayyibah, 2008), p. 689.

${ }^{85}$ al-Kirmânî, I, p. 167.

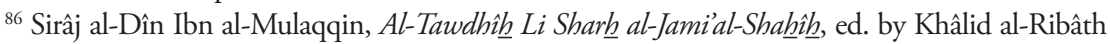
and Jum'ah Fathîi, 36 vols (Qathar: Wizârât al-Awqâf wa al-Shuûn al-Islâmiyyah, 2008), III, p. 103.

${ }^{87}$ Badr al-Dîn al-Damâmînî, Mashâbih Al-Jâmi', ed. by Muhamamad Nûr al-Dîn Thâlib, 10 vols (Dimashq - Bayrût: Dâr al-Nawâdir, 2009), I, pp. 135-36.

${ }^{88}$ Shams al-Dîn al-Barmâwî, Al-Lâmi' al-Shabîh , ed. by Muhammad Nûr al-Dîn Thâlib and others, 18 vols (Dimashq - Bayrût: Dâr al-Nawâdir, 2012), I, pp. 246-47.

${ }^{89}$ al-'Aynî, I, pp. 391-92.

${ }^{0}$ Jalâl al-Dîn al-Suyûthî, Al-Tawshîh $\underline{h}$ Sharh al-Jâmi'al-Shahîh $\underline{h}$, ed. by Ridhwân Jâmi' Ridhwân, Jâmi‘ Al-Saghîr. (al-Riyâdh: Maktabat al-Rushd, 1998), p. 206.

${ }^{91}$ Ahmad Ibn Muhammad al-Khathîb al-Qasthalânî, Irshâd Al-Sârî, ed. by 'Abd al-'Azîz al-Khâlidî, 15 vols (Bayrût: Dâr al-Kutub al-'Ilmiyyah, 1996), I, pp. 185-86.

${ }^{92}$ Abû Yahyâ Zakariyya' al-Anshârî, Tuhffat Al-Bârî, ed. by Sulaymân Ibn Duray' al-Âzimî, 10 vols (al-Riyâdh: Maktabat al-Rushd, 2005), I, p. 206.

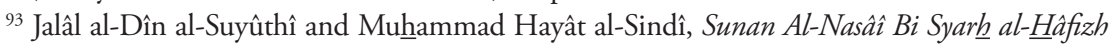

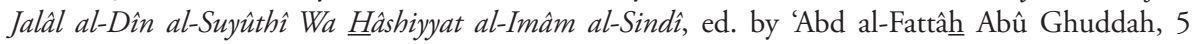
vols (Bayrût: Dâr al-Márifah, 1990), IV, p. 480.

${ }^{94}$ Muhammad Ibn 'Alî al-Athyûbî, Dhakhîrat Al-'Uqbâ, 42 vols (Bayrût: Dâr al-M'râj, 1996), xxxvII, pp. 250-60. 
of the narration of hadîth about the removal of a person's badness after converting to Islam in Sunan al-Nasâî as a confirmed narration pathway. The status of ta'lîq or mu'allaq in Shahîh al-Bukhârî, because al-Bukhârî states it in the form of jazm (not tamrîdh), is considered to be nonproblematic. Without denying the suspension (ta'lîq), the text (matn

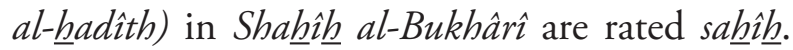

\section{a. Islam the First; Ideological Commentaries}

By referring to all the references above, matn al-hadith about the removal of a person's badness after converting to Islam has been explained by the scholars, both commentaries of Shabîh al-Bukhârî or Sunan alNasâi. All comments revolve around the Islam of someone who is an absolute condition, physically and mentally; inner and outer (al-bâthin wa al-zhâhir), ${ }^{95}$ for the acceptance of good deeds and the eradication of bad deeds. From these traditional commentaries, it is concluded in which the good deeds committed by non-Muslims (kâfir or mushrik) were rejected; cannot be judged to be good.

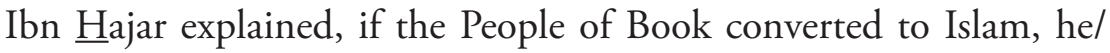
she would be rewarded twice as described in the Qur'an and authentic hadîth. Whereas if he/she dies while still following his/her former religion then all his goodness will not be useful or in vain. This indicates that the reward for the deeds done while he/she was still following his former religion, is also given and combined with the reward for his deeds after converting to Islam. ${ }^{96}$

Regarding the reward multiplication, Ibn $\underline{\text { Hajar rejected opinions }}$ that only understood the text literally. By citing a verse of 261 surah al-

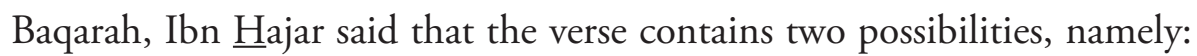
(1) it could be that the God multiplied it to reach 700; or (2) the God will multiply 700 to exceed that number, as the narration of al-Bukhârî of Ibn 'Abbâs in the chapter of "al-Riqâq." ${ }^{97}$ Allah decreed for him/

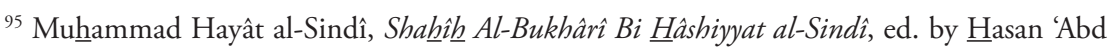
al-Âl and Haytham Khalîfah al-Tu'aymî (Bayrût: Sharikat Abnâ' Sharîf al-Anshârî, 2013), p. 20.

${ }^{96}$ Ibn $\underline{\text { Hajar, Fath }}$ Al-Bârî, III, pp. 211-12.

${ }^{97}$ al-Bukhârî̀, p. 1037. 
her 10 to 700 times of goodness and will (continue to) multiply it as much as possible. ${ }^{98}$

\section{b. Islam the Basic: Hadîth al-A $\underline{\text { Hâm }}$ Commentaries.}

Ibn ㅂajar cited al-Mazârî (Abû 'Abdillâh Muhammad Ibn 'Alî Ibn 'Umar al-Tamîmî [d. 536/1141])99 and al-Qâdhî al-'Ayyâdh (Ibn Mûsâ al-Yahshubî [d. 544/1149]) ${ }^{100}$ in which their argument of all the good deeds done by unbelievers cannot be accepted. All acts of righteousness that he/she has done in a shirk condition will not be rewarded. That is because one of the requirements for people who approach themselves is to have to know whom they are approaching. In this case, infidels and polytheists are not included in this group. In essence, ideologically, there is no reward for non-Muslims in the hereafter. ${ }^{101}$

Ibn ㅂajar quoted al-Nawawî (Abû Zakariyyâ Yahyâ Ibn Sharaf [d. 676/1277]) that believes in which non-Muslim who has done good deeds then converted to Islam and died in his Islam, then the reward for all his/ her good will be given. Al-Nawawî analogizes it to an infidel who has paid the expiation of zhihâr. ${ }^{102}$ When converting to Islam, in the discourse of fiqh al-islâm (Islamic jurisprudence) he (the infidel) did not necessary to repeat it. In this case, al-Nawawî seems to provide special conditions, that the acceptance of the merit of one's kindness is if a person has converted to Islam and he is good in his Islam. ${ }^{103}$ Al-Nawawî's view can be seen in fiqh al-islâm discourse and applies in all fiqh discussions. Islam of a person is a prerequisite for the adoption of taklîfî regulation.

${ }^{98}$ Ibn Hajar, Fath Al-Bârî, III, pp. 211-12.

99 Abû 'Abdillâh Muhammad Ibn 'Alî Ibn 'Umar al-Tamîmî al-Mazârî, Al-Múallim Bi Fawâid Muslim, ed. by Muhammad al-Shâdhilî al-Nayfur (Tûnis: Bayt al-Hikmah, 1987), p. 308.

${ }^{100}$ Ibn Mûsâ al-Yahshubî al-Qâdhî al-'Ayyâdh, Kitâb Al-Îmân Min Ikmâl al-Mu'allim Bi Fawâid Muslim, ed. by Husayn Ibn Muhammad Shawwâth (al-Riyâdh: Dâr al-Wathan, 1417), pp. 505-6.

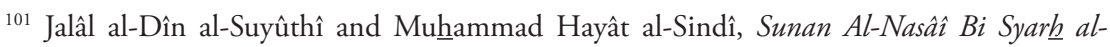

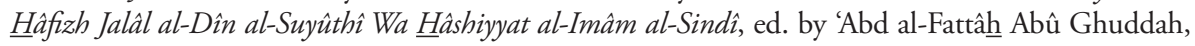
5 vols (Bayrût: Dâr al-Mảrifah, 1990), IV, p. 480.

102 Abû Zakariyyâ Yahyâ ibn Sharaf al-Nawawî, Al-Minhâjj Fî̀ Sharh Shahîh $\underline{h}$ Muslim Ibn Hajjâj ('Ammân al-Riyâdh: Bayt al-Afkâr, 2000), p. 171.

${ }^{103}$ al-Nawawî, Al-Minhâj Fî Sharh Shahîh Muslim Ibn Hajjâj, p. 171. 
Taklif is the term used for the package of religious obligations and duties ${ }^{104}$. This obligation package is charged to people who have fulfilled three main requirements, namely: islâm (Muslim, individuals who have converted to Islam), bulugh (person who has attained the age of puberty) ${ }^{105}$, and âqil (full possession of his mental faculties) ${ }^{106}$. There are many examples of discussions about the act of mukallaf (person who is responsible under the Islamic law) in the Islamic Jurisprudence ( $f q h$ al-islâm) ${ }^{107}$. Among them: al-'Allâf (al-'Allâf, 1417, p. 283), al-Jazâirî (al-Jazâirî, 1991, p. 414), al-Zuhaylî (al-Zuhaylî, 1985, p. 266), dan Hallâq (ㅂallâq, 2002, p. 555) in each of their works.

From the various explanations above, in the study of Islamic Jurisprudence (figh al-islâm), the relationship between a person's faith with his actions is inseparable ${ }^{108}$. Faith is manifested in the form of acceptance of all the provisions of $\operatorname{God}^{109}$. The embodiment was originally from the pledge of the oneness of God and the acceptance of Muhammad (PBUH) ${ }^{110}$. This is an entry point for the reciprocity of kindness in one's eschatological domain. Goodness in any form in this world, in the Islamic Jurisprudence view, without any foundation of faith is rejected; will not get the return of kindness in the afterlife, as explained in the hadith of al-Bukhârî, al-Nasâî and Ibn al-A'râbî above.

${ }^{104}$ Mohammed Ghaly, 'The Convention on the Rights of Persons with Disabilities and the Islamic Tradition: The Question of Legal Capacity in Focus', Journal of Disability \& Religion, 23.3 (2019), 251-78<https://doi.org/10.1080/23312521.2019.1613943>.

${ }^{105}$ Imran Ahsan Khan Nyazee, Islamic Jurisprudence - 3rd Edition (Islamabad: Advanced Legal Studies Institute, 2019), pp. 145-46.

${ }^{106}$ Olaf Köndgen, The Codification of Islamic Criminal Law in Sudan: Penal Codes and Supreme Court Case Law Under Numayrî and Al-Bashîr, Studies in Islamic Law and Society, volume 43 (Leiden: Brill, 2018), p. 297.

${ }^{107}$ Johansen Baber, The Changing Limits of Contingency in the History of Muslim Law (Jerusalem: The Nehemia Levtzion Center for Islamic Studies, The Institute for Asian and African Studies, The Hebrew University of Jerusalem, 2013), p. 23.

${ }^{108}$ Judith Frishman and Umar Ryad, 'Islamic and Jewish Legal Traditions', in The Routledge Handbook of Muslim-Jewish Relations, ed. by Josef Meri (New York - London: Routledge, 2016), p. 158.

${ }^{109}$ Sachiko Murata and William Chittick, The Vision of Islam: The Foundations of Muslim Faith and Practice (London: I. B. Tauris, 1996), p. 123.

${ }^{110}$ Jacob Lassner and Michael Bonner, Islam in the Middle Ages: The Origins and Shaping of Classical Islamic Civilization (Santa Barbara: Praeger, 2010), p. 51. 


\section{Conclusion}

The narrations of hadith regarding the removal of a person's badness after converting to Islam are found, at least, in three books in the category al-mashâdir al-ashliyyah (the original sources), namely: Shahîh al-Bukhârî, Sunan al-Nasầ, and al-Mu'jam li Ibn al-A 'râbî. Of the three books, the status sanad in Shahîh al-Bukhârî was mu'allaq. While in Sunan al-Nasâî and al-Mu'jam li Ibn al-A'râbî were muttashil status. The degree of hadîth regarding the elimination of a person's badness after converting to Islam

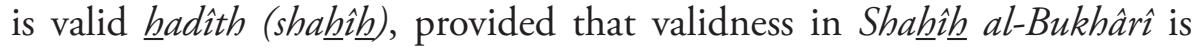
determined after being explained by the scholars; commentator Shahîh $\underline{h}$ alBukhârî, except Ibn $\underline{\text { Hazm }}$ who has given a separate note. The implication of this degree of $\underline{h} a d \hat{t} t h$ can be seen in some other works outside $\underline{H} a d \hat{t} t h$. Found some verses of the Qur'ân which are given an explanation with the narration of this hadith in its position as the tafsir bi al-ma'thîr and the fiqh works. Thus, this hadith is seen adorning or coloring the works of other scholars outside the works of hadith. In the discourse tradition

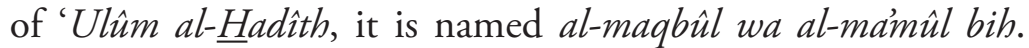

\section{Bibliography}

'Abdalî, Ibn Maqshad al-, al-Qâdhî: 'Alâ Ta'lîqât al-Bukhârî. Dâr Nûr al-Yaqîn, 2012

Abdul Jabbar, Ghassan, 'The Classical Tradition', in The Wiley Blackwell Concise Companion to the Hadith, ed. by Daniel W. Brown, The Wiley Blackwell Companions to Religion Hoboken, NJ: John Wiley \& Sons, Inc, 2019.

Abû Dâwud, Sulaymân Ibn al-Ash'ath al-Sijistânî, Sunan Abî Dâwud, ed. by Râid Ibn Shabrî Ibn Abî 'Alfah. al-Riyâdh: Dâr al-ㅍadhârah, 2015. 'Allâf, 'Abdullâh Ibn Ahmadal-, Min Fatâwâa Aimmat Al-Islâm Fî̀ alShiyâm. al-Riyâdh: Dâr al-Tharafayn, 1417.

Anshârî, Abû Yahyâ Zakariyya’ al-, Tuhfat Al-Bârî, ed. by Sulaymân Ibn Duray' al-Âzimî, 10 vols. al-Riyâdh: Maktabat al-Rushd, 2005.

Athyûbî, Muhammad Ibn 'Alî al-, Dhakhîrat Al-'Uqbâ, 42 vols. Bayrût: Dâr al-M’râj, 1996. 
'Aynî, Muhammad Ibn Aḥmad al-, 'Umdat al-Qârî, ed. by 'Abdullâh Mahmûd Muhammad 'Umar, 25 vols. Bayrût: Dâr al-Kutub al'Ilmiyyah, 2001.

Baber, Johansen, The Changing Limits of Contingency in the History of Muslim Law. Jerusalem: The Nehemia Levtzion Center for Islamic Studies, The Institute for Asian and African Studies, The Hebrew University of Jerusalem, 2013.

Baghdâdî, Al-Khathîb al-, Ta'rîkh Madînat Al-Salâm, ed. by Bashshâr 'Awwâd Ma'rûf, 17 vols. Bayrût: Dâr al-Gharb al-Islâmî, 2001.

Bâhûu, Abû Sufyân Mushthafâ,, Al-'Illah Wa Ajnâsuhâ inda al-Muhaddithîn. Thanthâ: Dâr al-Dhiyầ, 2005.

Barmâwî, Shams al-Dîn al-, Al-Lâmi' al-Shabîh Nûr al-Dîn Thâlib, Muhammad Khallûf 'Abdullâh, 'Abd al-Rahmân Muhammad al-Kishk, Muhammad Rashâd Syams, Yâsîn 'Abd alRahmân Jamûl, and Muhammad 'Abd al-Rahmân al-Khathîb, 18 vols. Dimashq - Bayrût: Dâr al-Nawâdir, 2012.

Bilâl, Sa'd Fahmî Aḥmad, Al-Sirâj al-Munîr Fî Alqâb al-Muhaddithîn. al-Riyâdh: Maktabat al-Tawbah - Dâr Ibn Hazm, 1993.

Brown, Jonathan, The Canonization of Al-Bukhârî and Muslim: The Formation and Function of the Sunnî Hadith Canon. Leiden: BRILL, 2007.

, The Canonization of Al-Bukhari and Muslim: The Formation and Function of the Sunnihadith Canon., ed. by Wadad Kadi and Rotraud Wielandt. Leiden; Boston: Brill, 2007.

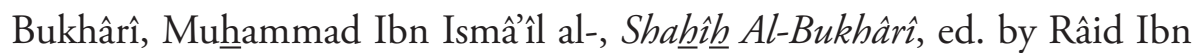

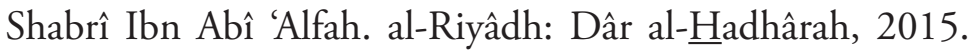

Damâmînî, Badr al-Dîn al-, Mashâbih Al-Jâmi, ed. by Muhammad Nûr al-Dîn Thâlib, 10 vols. Dimashq - Bayrût: Dâr al-Nawâdir, 2009.

Dâruquthnî, 'Alî Ibn 'Umar Ibn Ahmad al-, Al-Dhu'afâ Wa al-Matrûkîn, ed. by Muhammad Ibn Luthfî al-Shabbâgh. Bayrût-Dimashq: alMaktab al-Islâmî, 1980.

Dhahabî, Shams al-Dîn Abû 'Abdillâh Muhammad ibn Ahmad al-Dimashqî al-, Mîzân Al-I'tidâl Fî̀ Naqd al-Rijâl, ed. by 'Alî Muhammad alBajâwî, 4 vols. Bayrût: Dâr al-Mảrifah, 1963. 
Mîzân Al-I'tidâl Fî̀ Naqd al-Rijâl, ed. by 'Alî Muhammad alBajâwî, 4 vols (Bayrût: Dâr al-Ma’rifah, 1963.

-, Siyar A'lâm al-Nubâlâ', ed. by Shu'ayb al-Arnâûth and Muhammad Na'îm al-'Arqasûsî, 25 vols. Bayrût: Muassasat al-Risâlah, 1982.

- Târîkh Al-Islâm Wa Wafayât al-Mashâhîr Wa al-A'lâm, ed. by 'Umar 'Abd al-Salâm Tadmûrî, 53 vols. Bayrût: Dâr al-Kitâb al'Arabî, 1991.

Fadel, Mohammad, 'Ibn Hajar's Hady al-Sârî: A Medieval Interpretation

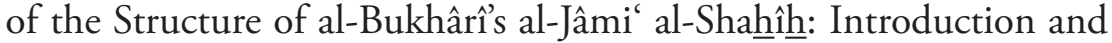
Translation', Journal of Near Eastern Studies, 54.3 (1995).

Fadhlî, 'Abdalhâdî al, Introduction to Hadîth. London: ICAS Press, 2011. Frishman, Judith, and Umar Ryad, 'Islamic and Jewish Legal Traditions', in The Routledge Handbook of Muslim-Jewish Relations, ed. by Josef Meri. New York - London: Routledge, 2016.

Gacek, Adam, The Arabic Manuscript Tradition: A Glossary of Technical Terms and Bibliography, Handbuch Der Orientalistik = Handbook of Orientalistik. Section One, the Near and Middle East, v. 58. Leiden; Boston: Brill, 2001.

Ghaly, Mohammed, 'The Convention on the Rights of Persons with Disabilities and the Islamic Tradition: The Question of Legal Capacity in Focus', Journal of Disability \& Religion, 23.3 (2019), 251-78 <https://doi.org/10.1080/23312521.2019.1613943>

Graham, William A., 'Traditionalism in Islam: An Essay in Interpretation', The Journal of Interdisciplinary History, 23.3 (1993), 495-522 <https://doi.org/10.2307/206100>

hadithportal, 'Jâmi' al-Sunnah Wa Shurûhuhâ', Jâmi' al-Sunnah Wa Shurûhuhâ, 2019 <https://www.hadithportal.com/>. Accessed 17 December 2019.

Hallâq, Muhammad Shubhîi ibn Hasan, Al-Lubâb Fî̀ Fiqh al-Sunnah Wa al-Kitâb. al-Imârât - al-Qâhirah: Maktabat al-Shahâbah - Maktabat al-Tâbiîiin, 2002.

Hasan, Shuhayb, Al-Márifah Fî̀ 'Ulûm al-Hadîth (an Introduction to the Science of Hadith). al-Riyâdh: Dâr al-Salâm, t.t. 


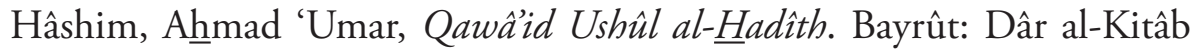
al-'Arabî, 1984.

Henry, Declan, Voices of Modern Islam: What It Means to Be Muslim Today. London - Philadelphia: Jessica Kingsley Publishers, 2018

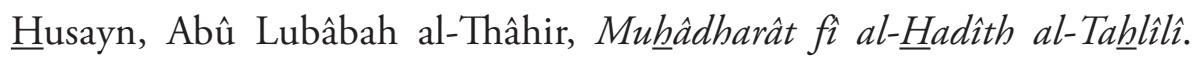
Bayrût: Dâr al-Gharb al-Islâmî, 2004.

Ibn al-Jawzî, Jamâl al-Dîn 'Abd al-Raḥmân, Al-Dhu'afầ Wa al-Matrûkîn, ed. by Abû al-Fidâ' 'Abdullâh al-Qâdhî, 2 vols. Bayrût: Dâr al-Kutub al-'Ilmiyyah, 1986.

Ibn al-Mulaqqin, Sirâj al-Dîn, Al-Tawdhîh Li Sharh al-Jamial-Shahîh $\underline{\text { h }}$ ed. by Khâlid al-Ribâth and Jum'ah Fathîi, 36 vols. Qathar: Wizârât al-Awqâf wa al-Shuûn al-Islâmiyyah, 2008.

Ibn A'râbî, Ahmad Ibn Muhammad Ibn Ziyâd, Al-Mủjam Li Ibn al-

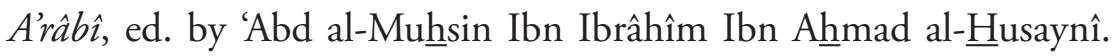
Jiddah: Dâr Ibn al-Jawzî, 1997.

Ibn 'Âshûr, Muhammad, Tafsîr al-Adl wa al-I'tidâl. QuranicThought. com, 2004.

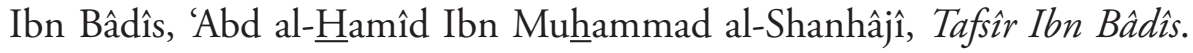
Bayrût: Dâr al-Kutub al-'Ilmiyyah, 2009.

Ibn Baththâl, 'Alî Ibn Khalaf Ibn 'Abd al-Malik, Sharh Shahîh $\underline{h}$ Al-Bukhârî Li Ibn Baththâl, ed. by Abû Tamîm Yâsir Ibn Ibrâhîm, 11 vols. alRiyâdh: Maktabat al-Rushd, 2003.

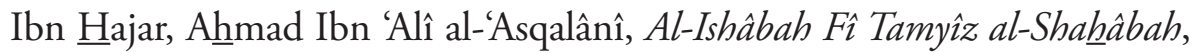
ed. by 'Âdil Aḥmad 'Abd al-Mawjûd and 'Alî Muhammad Mu'awwadh, 8 vols. Bayrût: Dâr al-Kutub al-'Ilmiyyah, 1995.

, Fath Al-Bârî, ed. by Shu'ayb al-Arnaûth and 'Âdil Murshid, 24 vols. Bayrût: Muassasat al-Risâlah, 2013.

- Hady al-Sârî Muqaddimat Fath al-Bârî, ed. by 'Abd al-Rahmân b. Nâshir al-Barrâk and Abû Qutaybah Nazhr Muhammad al-Fâriyâbî. al-Riyâdh: Dâr Thayyibah, 2005.

Lisân al-Mîzân, ed. by 'Abd al-Fattâh Abû Ghuddah and Salmân 'Abd al-Fattâh Abû Ghuddah, 10 vols. Bayrût: Dâr al-Bashâir alIslâmiyyah, 2002. 
Lisân al-Mîzân, ed. by 'Abd al-Fattâh Abû Ghuddah and Salmân 'Abd al-Fattâh Abû Ghuddah, 10 vols. Bayrût: Dâr al-Bashâir alIslâmiyyah, 2002.

—, Taghlîq Al-Ta'lîq, ed. by Sa'îd 'Abd al-Rahmân Mûsâ al-Qazaqî̀, 5 vols. Bayrût - Dimashq: al-Maktab al-Islâmî - Dâr 'Ammâr, 1985.

—, Taqrîb Al-Tahdhîb, ed. by Ầdil Murshid. Bayrût: Muassasat al-Risâlah, 1999.

Ibn Hibbân, Abû Hâtim Muhammad, Kitâb Al-Thiqât, ed. by Ibrâhîm Shams al-Dîn and Turkî Farhân al-Mushthafâ, 5 vols. Bayrût: Dâr al-Kutub al-'Ilmiyyah, 1998.

Ibn 'Abd al-Hâdî, 'Abd al-Muhdî ibn 'Abd al-Qâdir, Thuruq Al-Takhrîj Hadîth. al-Qâhirah: Dâr al-I'tishâm, 1987.

Ibn 'Abd al-Qâdir, Muwaffaq ibn 'Abd Allâh., Tawthîq Al-Nushûsh Wa-Dhabthuhâ inda al-Muhaddithîn Makkah al-Mukarramah: alMaktabah al-Makkîyah, 1993.

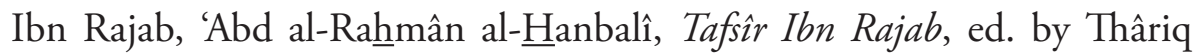
Ibn 'Awdh al-Lâh Muhammad, 2 vols. al-Riyâdh: Dâr al-Âshimah, 2001.

Jazâirî, Abû Bakr Jâbir al-, Minhâj Al-Muslim. Jiddah: Dâr al-Salâm, 1991.

Kirmânî, Muhammad Ibn Yûsuf al-, Al-Kawâkib al-Darârî, ed. by Muhammad Muhammad 'Abd al-Lathîf, 25 vols. Bayrût: Dâr Ihyầ al-Turâth al-Arabî, 1937.

Köndgen, Olaf, The Codification of Islamic Criminal Law in the Sudan: Penal Codes and Supreme Court Case Law Under Numayrî and AlBashîr, Studies in Islamic Law and Society, volume 43 Leiden: Brill, 2018.

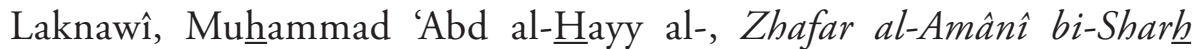
Mukhtashar al-Sayyid al-Sharîf al-Jurjânî fî Mushthalah al- $\underline{\text { Hadîth, }}$ ed. by Khalîl 'Imrân al-Manshûr. Bayrût: Dâr al-Kutub al-'Ilmiyyah, 1998.

Lassner, Jacob, and Michael Bonner, Islam in the Middle Ages: The Origins and Shaping of Classical Islamic Civilization. Santa Barbara: Praeger, 2010. 


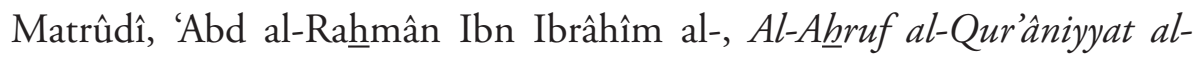
Sab’ah. al-Riyâdh: Dâr 'Âlam al-Kutub, 1991.

Mazârîa 1-, Abû 'Abdillâh Muhammad Ibn 'Alî Ibn 'Umar al-Tamîmî, Al-Mu'allim Bi Fawâid Muslim, ed. by Muhammad al-Shâdhilî alNayfur. Tûnis: Bayt al- $\underline{H}$ ikmah, 1987.

Mîsâwî, Umm 'Abdillâh al-, 'Abû Ja'far Ibn Abî Shaybah (Nahw 210297 H)', 'Aqîdat al-Salaf al-Shâlih, 2009 <http://as-salaf.com/article. php?aid=31\&lang=ar>. Accessed 21 December 2019.

Mizzî, Jamâl al-Dîn Yûsuf Abû al-ㅂajjâj al-, Tahdhîb Al-Kamâl Fî̀ Asmầ al-Rijâl, ed. by Bashshâr 'Awwâd Ma'rûf, 35 vols. Bayrût: Muassasat al-Risâlah, 1992.

—, Tahdhîb Al-Kamâl Fî̀ Asmâ' al-Rijâl, ed. by Bashshâr 'Awwâd Ma’rûf, 35 vols. Bayrût: Muassasat al-Risâlah, 1992.

Murata, Sachiko, and William Chittick, The Vision of Islam: The Foundations of Muslim Faith and Practice. London: I. B. Tauris, 1996.

Muslimî, Muhammad Muhdî al-, Ashraf Manshûr 'Abd al-Rahmân, 'Ishâm 'Abd al-Hâdî Mahmûd, Aḥmad 'Abd al-Razzâq 'Îd, Ayman Ibrâhîm al-Zâmilî, and Mahnûd Muhammad Khalîl, Mawsî̀at

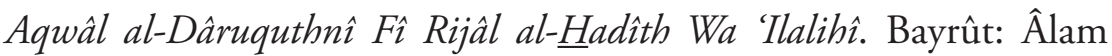
al-Kutub, 2001.

Mustapha, Sani Salih, Sciences of Hadith Literature. Wiltshire: Paragon Publishing, 2017.

Nasâî, Ahmad Ibn Shu'ayb Ibn 'Alî Ibn Sinân al-, Sunan Al-Nasầ̂, ed. by Râid Ibn Shabrî Ibn Abî 'Alfah. al-Riyâdh: Dâr al-Hadhârah, 2015.

Nawawî, Abû Zakariyyâ Yahyâ ibn Sharaf al-, Al-Minhâj Fî Sharh Shahîh Muslim Ibn Hajjâj 'Ammân al-Riyâdh: Bayt al-Afkâr, 2000.

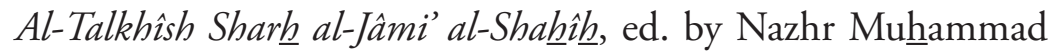
al-Fâriyâbî Abû Qutaybah al-Riyâdh: Dâr Tayyibah, 2008.

Nyazee, Imran Ahsan Khan, Islamic Jurisprudence - 3rd Edition. Islamabad: Advanced Legal Studies Institute, 2019.

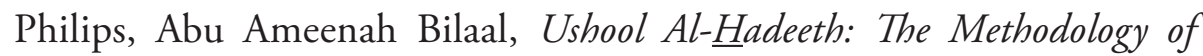
Hadith Evaluation. Riyadh: International Islamic Publishing House, 2007. 
Qâsimî, Ibrâhîm Ibn 'Abdillâh al-, Taqrîb Ishthilâh al-Munaddithîn min Ifhâm al-Thâlibîn. al-Qâhirah: Dâr al-Hilâl li al-Kutub al-Islâmiyyah, 1985.

Qâdhî al-'Ayyâdh, Ibn Mûsâ al-Yahshubî al-, Kitâb Al-Î́mân Min Ikmâl al-Mu'allim Bi Fawâid Muslim, ed. by Husayn Ibn Muhammad Shawwâth. al-Riyâdh: Dâr al-Wathan, 1417.

Qasthalânî, Ahmad Ibn Muhammad al-Khathîb al-, Irshâd Al-Sârî, ed. by 'Abd al-'Azîz al-Khâlidî, 15 vols. Bayrût: Dâr al-Kutub al-'Ilmiyyah, 1996.

Qudhâ'î, Muhammad ibn Salâmah, A Light in the Heavens: Sayings of the Prophet Muhammad, trans. by Tahera Qutbuddin. New York: New York University, 2019.

Sentürk, Recep, Narrative Social Structure: Anatomy of the Hadith Transmission Network, 610-1505 California: Stanford University Press, 2005.

Shahrazûrî, Abû 'Amr 'Uthmân Ibn 'Abd al-Rahmân Ibn al-Shalâh al-,

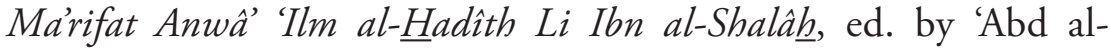
Lathîf al-Hamîm and Mâhir Yâsîn al-Fahll. Bayrût: Dâr al-Kutub al-'Ilmiyyah, 2002.

Shayakhmetov, Olzhas Mirzakhanovich, 'On the Metalanguage of Modern Arabic Lexicography', Review of European Studies, 7.6 (2015), 2092016 <https://doi.org/10.5539/res.v7n6p209>

Shuayb, Fiazuddin, “Who's Better than God to Rule?" - An Inquiry into the Formation of the First Islamic State (622-32 CE)' (University of California, 2012) <https://escholarship.org/uc/item/87q494b4>.

Sindî, Muhammad Hayât al-, Shahîh $\underline{h}$ Al-Bukhârî Bi Hâashiyyat al-Sindî̀,

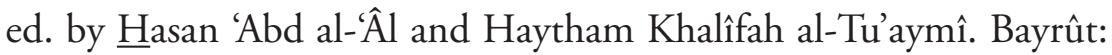
Sharikat Abnâ' Sharîf al-Anshârî, 2013.

Siregar, Nurkhalijah, 'Kitab Sunan An-Nasầî (Biografi, Sistematika, Dan Penilaian Ulama)', Hikmah, 15.1 (2018).

Sodiq, Yushau, Insider's Guide to Islam. Bloomington: Trafford On Demand Publishing, 2011.

Suyûthî, Jalâl al-Dîn al-, Al-Jâmi“ al-Shaghîr Fî Ahâdîth al-Bashîr Wa-alNadhîr, Jâmi' Al-Saghîr. Bayrût: Dâr al-Kutub al-'Ilmîyah, 2004. 
, Al-Tawshîh Sharh al-Jâmi'al-Shahîh $\underline{h}$, ed. by Ridhwân Jâmi' Ridhwân, Jâmi` Al-Saghîr. al-Riyâdh: Maktabat al-Rushd, 1998.

—, and Muhammad Hayât al-Sindî, Sunan Al-Nasâî Bi Syarh alHâfizh Jalâl al-Dîn al-Suyûthî Wa Hâshiyyat al-Imâm al-Sindî̀, ed. by 'Abd al-Fattâh Abû Ghuddah, 5 vols. Bayrût: Dâr al-Ma'rifah, 1990. Thahhân, Mahmûd al-, Ushûll Al-Takhrîj Wa-Dirâsat al-Asânîd. al-Qâhirah: Dâr al-Kutub al-Salafîyyah, 1982.

Wâdi'î, Muqbil Ibn Hâdî al-, Tarâjum Rijâl Al-Dâruquthnî Fî Sunanihî al-Ladhî Lam Yatarajjam Lahum Fî̀ al-Taqrîb Wa Lâ Fî̀ Rijâl al$\underline{H} a k i m$, ed. by Ahmad Ibn Muhammad al-Qadasî, Maqbûl Ibn 'Alî al-Wajîh, Muhammad Ibn 'Abdillâh al-Sayyâghî, and Shâlih Ibn Qâyid al-Wâdi’î Shan'â': Dâr al-Âthâr; Muassasat al-Rayyân.

Wensinck, Arent Jan, Johan Peter Mari Mensing, and Jan Brugman, Al-Mu'jam al-Mufahras Li Alfâzh al-Hadîth al-Nabawî: 'an al-Kutub al-Sittah Wa 'an Musnad al-Dârimî Wa Muwaththa'Mâlik Wa-Musnad

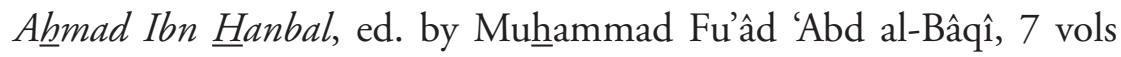
Leiden: Brill, 1936.

Zaman, Iftikhar, "The Science of "Rijâl" as a Method in the Study of Hadiths', Journal of Islamic Studies, 5.1 (1994).

Zuhaylî, Wahbah al-, Al-Figh al-Islâmî Wa Adillatuh, 10 vols. Dimashq: Dâr al-Fikr, 1985. 